\title{
Tests of new instrument for measuring Dublin descriptors
}

Citation for published version (APA):

Allen, J. P., \& Ramaekers, G. W. M. (2008). Tests of new instrument for measuring Dublin descriptors. ROA. ROA Technical Reports No. 005 https://doi.org/10.26481/umarot.2008005

Document status and date:

Published: 01/01/2008

DOI:

10.26481/umarot.2008005

Document Version:

Publisher's PDF, also known as Version of record

\section{Please check the document version of this publication:}

- A submitted manuscript is the version of the article upon submission and before peer-review. There can be important differences between the submitted version and the official published version of record.

People interested in the research are advised to contact the author for the final version of the publication, or visit the DOI to the publisher's website.

- The final author version and the galley proof are versions of the publication after peer review.

- The final published version features the final layout of the paper including the volume, issue and page numbers.

Link to publication

\footnotetext{
General rights rights.

- You may freely distribute the URL identifying the publication in the public portal. please follow below link for the End User Agreement:

www.umlib.nl/taverne-license

Take down policy

If you believe that this document breaches copyright please contact us at:

repository@maastrichtuniversity.nl

providing details and we will investigate your claim.
}

Copyright and moral rights for the publications made accessible in the public portal are retained by the authors and/or other copyright owners and it is a condition of accessing publications that users recognise and abide by the legal requirements associated with these

- Users may download and print one copy of any publication from the public portal for the purpose of private study or research.

- You may not further distribute the material or use it for any profit-making activity or commercial gain

If the publication is distributed under the terms of Article $25 \mathrm{fa}$ of the Dutch Copyright Act, indicated by the "Taverne" license above, 


\title{
Tests of new instrument for measuring Dublin Descriptors
}

\author{
Jim Allen \\ Ger Ramaekers
}

ROA-TR-2008/5

November 2008

Research Centre for Education

and the Labour Market

P.O. Box 616

6200 MD Maastricht

The Netherlands

$\begin{array}{ll}\text { E-mail: } & \text { secretary@roa.unimaas.nl } \\ \text { Internet: } & \text { www.roa.unimaas.nl }\end{array}$

Maastricht University

Faculty of Economics and Business Administration 
ISBN 978-90-5321-469-5

Sec08.142.pdf 


\section{Contents}

1 Introduction 1

2 Item non-response 9

3 Distribution 13

4 Differentiation between categories 20

5 Predictive validity 28

6 Required level versus importance 35

7 General versus specific items 38

8 Conclusions 46

Appendix 1: Operationalisatie Dublin descriptoren 51

Appendix 2: Original O*NET items 72 



\section{Introduction}

In the summer of 2007 a new instrument was developed which aimed at providing an operationalisation of the Dublin descriptors (Appendix 1). Special attention was paid thereby to the so-called 'anchor problem' inherent in most self-assessments: the lack of an objective frame of reference against which different respondents can assess their own level of competence.

The instrument consists of a combination of general and specific items. First of all a general item was formulated for each of the 5 Dublin descriptors. The general items were formulated in such a way as to match the original descriptors as closely as possible. Anchors were developed for each of these items which correspond to junior college, bachelors and masters levels. For example, for the item "communication" the junior college level was indicated by the anchor "is able to transmit information", the bachelors level by "is able to communicate ideas and transmit solutions" and the master level by "is able to communicate conclusions and the knowledge, motivations and considerations that underlie these conclusions in a convincing manner". The anchors for the bachelors and masters level are derived more or less directly from the Dublin descriptors, and those for the junior college level are based on the European Qualification Framework. For practical reasons it was decided not to develop anchors for the $\mathrm{PhD}$ level. The anchors were placed in a scale ranging from 1 to 8 , with the junior college level being assigned a scale value of 2 , the bachelors level the value 5 and the masters level the value 7 . This allowed respondents the option of choosing a level above masters level or below junior college level if they find that appropriate. The distances between junior college, bachelors and masters level approximates the mean differences in years of education corresponding to each level.

In addition to these general items, 2 or 3 more specific questions were included for each descriptor. These were borrowed from the O*NET survey (Appendix 2), a large-scale study carried out in the United States among a large sample of the workforce (see http://www.onetcenter.org). For several reasons it was necessary to 
adapt the $\mathrm{O}^{*} \mathrm{NET}$ anchors. First of all it was necessary to restrict the range, to avoid very low levels which would more or less obviously not apply to bachelors and masters. Secondly, the O*NET anchors are not specifically designed to correspond to the junior college, bachelors and masters levels. In consultation with a Dutch occupational specialist, changes were made to the anchors to make them correspond as closely as possible to these three levels in Dutch education.

The advantage of the general items is that they correspond more or less exactly to the Dublin descriptors and are as such immediately recognizable for respondents. There are however several disadvantages: a 'halo-effect' may occur, whereby answers to earlier questions influence answers to later questions), and the anchors may be formulated in such general terms that they can be interpreted in several ways. The advantage of the specifically formulated O*NET items is that they concern concrete situations, and are thus more strongly fixed. There are again several disadvantages: they may sometimes refer to situations that are unfamiliar to some respondents, and they may be more demanding for respondents, because they require them to 'translate' the specific situation described in the anchor to an equivalent situation from their own experience or knowledge. Finally, the specific items cover only part of the descriptors.

For each of the items 4 questions were asked:

1. How important is the aspect for performing your current job? (score ranging from 1 'not important' to 5 'extremely important');

2. What level is necessary on this aspect for adequate performance of your current job? (8-point scales with anchors at the junior college (2), bachelors (5) and masters (7) level;

3. How would you assess your own level on this aspect? (same scale as 2);

4. Would you have preferred more or less attention to have been paid to developing this aspect in your study program (score ranging from 1 'much more attention' to 5 'much less attention). 
The tests described in this note focus mainly on questions 2 and 3, which form the key innovation aimed for measuring the Dublin descriptors. The first question was included because it is a much simpler question used in many studies, and can serve as something of a benchmark for question 2. In order to merit further development this more complicated question of required level must yield information over and above what can be obtained by simply asking how important the aspect in question is. In combination, questions 2 and 3 can yield information on shortages and surpluses. Of course, a shortage need not mean that the item in question was insufficiently developed in education. It may be that some aspects are better developed at work or in private life. For this reason the last question was added, to see explicitly whether sufficient attention was paid to the aspect in question.

In the autumn of 2007 a pilot study was carried out among a random $10 \%$ sample of Higher Vocational Education (HBO) and university (WO) graduates approached for the annual graduate surveys (the HBO-Monitor and WOMonitor). To glean more information from the pilot study, 4 versions of the questionnaire were developed:

1. the list as described above, with anchors for junior college, bachelors (HBO) and masters (university) level, with for each item first the question on importance, followed by a combined question on required and own level, and closing with the question on preferred level of attention;

2. the same as 1, starting with own level, followed by importance, required level and attention;

3. the same as 1, but with a fixed scale without anchors for the questions on required and own level;

4. the same as 1 , but with the original $\mathrm{O}^{*} \mathrm{NET}$ anchors.

Scheme 1 summarizes the characteristics of the regular list and the four above mentioned list from the pilot study. 


\begin{tabular}{llllll}
\hline & Regular list & List 1 & List 2 & List 3 & List 4 \\
\hline Anchors for level & No & MBO/HBO/WO & MBO/HBO/WO & No & O*NET \\
Scale for level & 5-point & 8-point & 8-point & 8-point & 8-point for 5 \\
& & & & items; \\
& & & & & 7-point for 11 \\
items
\end{tabular}

In the pilot we want to research the psychometric properties of the different types of questions: do we measure the same? How does it sit with the construct and predictive validity in relation to other variables? Can a reduction of the number of questions be reached?

By comparing the outcomes of these 4 versions of the new instrument with each other and with the instrument currently used in the rest of the HBO-Monitor and WO-Monitor, it is possible to test a number of explicit hypotheses:

\section{Anchors versus no anchors}

Item non-response (null) hypothesis 1: Scales using clearly defined anchors representing the hypothetical range of competences in the population do not lead to more item non-response than scales without anchors.

Overestimation hypothesis 1: Scales using clearly defined anchors representing the hypothetical range of competences in the population will be less susceptible to overestimation than scales without anchors. 
Distribution hypothesis 1: Scales using anchors representing the hypothetical range of competences in the population will more closely approximate a normal distribution than scales without anchors.

Distribution hypothesis 2: Scales using anchors representing the hypothetical range of competences in the population will be more likely to elicit answers across the full range than scales without anchors.

Distribution hypothesis 3: Scales using anchors representing the hypothetical range of competences in the population will be less susceptible to left or right censuring than scales without anchors.

Differentiation hypothesis 1 (weak version): Scales using anchors representing the hypothetical range of competences in the population will differentiate more on own level between bachelors and masters graduates than scales without anchors.

Differentiation hypothesis 1 (strong version): Scales using anchors representing the hypothetical range of competences in the population will yield a mean own level of close to 5 for bachelors and close to 7 for masters; scales without anchors will yield no consistent mean level for bachelors or masters.

Differentiation hypothesis 2: Scales using anchors representing the hypothetical range of competences in the population will differentiate more on own level between study programs than scales without anchors.

Differentiation hypothesis 3 (weak version): Scales using anchors representing the hypothetical range of competences in the population will differentiate more on required level between graduates holding jobs that require bachelors level and those holding jobs requiring masters level qualifications than scales without anchors. 
Differentiation hypothesis 3 (strong version): Scales using anchors representing the hypothetical range of competences in the population will yield a required own level of close to 5 for graduates holding bachelors-level jobs and close to 7 for graduates holding masters-level jobs; scales without anchors will yield no consistent mean required level for bachelors or masters level jobs.

Differentiation hypothesis 4: Scales using anchors representing the hypothetical range of competences in the population will differentiate more on required level between occupations than scales without anchors.

Prediction hypothesis 1: Scales using clearly defined anchors representing the hypothetical range of competences in the population to measure own competences will be better predictors of graduates' general evaluation of the study program than scales without anchors.

Prediction hypothesis 2: Scales using clearly defined anchors representing the hypothetical range of competences in the population to measure own and required competences will be better predictors of graduates' labour market outcomes than scales without anchors.

\section{O*NET anchors versus adapted anchors}

Distribution hypothesis 4: Scales using anchors adapted to the Dublin descriptors will show better distributional characteristics than scales using the original O*NET anchors.

Differentiation hypothesis 5: Scales using anchors adapted to the Dublin descriptors will differentiate more between educational and occupational levels and fields than scales using the original $\mathrm{O}^{*} \mathrm{NET}$ anchors. 
Prediction hypothesis 3: Scales using anchors adapted to the Dublin descriptors to measure own and required competences will be better predictors of educational and labour market outcomes than scales using the original O*NET anchors.

Item non-response hypothesis 2: Scales using anchors adapted to the Dublin descriptors lead to less item non-response than scales using the original O*NET anchors.

\section{Importance versus required level}

Distribution hypothesis 5: Required level based on anchors representing the hypothetical range of competences in the population will show better distributional characteristics than importance based on scales without anchors.

Differentiation hypothesis 6: Required level based on anchors representing the hypothetical range of competences in the population will differentiate more between educational and occupational levels and fields than importance based on scales without anchors.

Prediction hypothesis 4: Required level based on anchors representing the hypothetical range of competences in the population to measure own competences will be better predictors of labour market outcomes than importance based on scales without anchors.

Item non-response (null) hypothesis 3: Required level based on anchors representing the hypothetical range of competences in the population does not lead to more item non-response than importance based on scales without anchors.

Discrepancy hypothesis 1: Discrepancies (shortages and surpluses) between own and required level based on anchors representing the hypothetical range of competences in the population are better indicators of overall shortages and surpluses than discrepancies between (standardized) importance and (standardized) own level. 


\section{General versus specific items}

Overestimation hypothesis 2: Items with situation-specific anchors for own and required level will be less susceptible to overestimation than items with generalized anchors.

Distribution hypothesis 4: Items with situation-specific anchors for own and required level will show better distributional characteristics than items with generalized anchors.

Differentiation hypothesis 5: Items with situation-specific anchors for own and required level will differentiate more between educational and occupational levels and fields than items with generalized anchors.

Prediction hypothesis 3: Items with situation-specific anchors for own and required level will be better predictors of educational and labour market outcomes than items with generalized anchors.

\section{Question order}

Distribution (null) hypothesis 6: It makes no difference for the distribution of answers whether the question on own level or the question on importance is asked first.

Differentiation (null) hypothesis 7: It makes no difference for the differentiation between educational and occupational levels and fields whether the question on own level or the question on importance is asked first.

Prediction (null) hypothesis 5: It makes no difference for the prediction of graduates' general evaluation of the study program or labour market outcomes whether the question on own level or the question on importance is asked first. 
Item non-response (null) hypothesis 4: It makes no difference for item non-response whether the question on own level or the question on importance is asked first.

\section{Item non-response}

Table 1 summarizes the progressive number of item missing values immediately preceding, during and immediately following the competence block. Since the progression is more or less linear over the course of the block (almost, but not quite; see discussion below), we limit the presentation to the first and last items in the competence list, and the questions immediately preceding the competence block.

Somewhat puzzlingly, prior to the competence block, the respondents who were selected to complete one of the four new lists of 'Dublin' competences already showed a higher level of item non-response. However, the difference is not statistically significant and can probably be put down to random sampling differences. Turning to the competence block, a second seemingly strange finding appears, namely that the item non-response on the dimensions importance and required level for the first 'Dublin' item drops substantially with respect to the immediately preceding question in all four versions. This finding is a little misleading however, since these percentages exclude those not currently in paid employment. When we turn to the first answers on the dimensions own level and attention wanted - for which no such selection applied - we see that the percentages are similar or slightly higher to that on the preceding item. For the regular list, the item non-response for required and own level on the first items is substantially higher than that on the comparable 'Dublin' questions, despite the lower level on the preceding item. This may be attributable to the fact that the regular list is programmed to show several items together on one screen. 
List

Regular list Dublin $1 \quad$ Dublin $2 \quad$ Dublin $3 \quad$ Dublin 4

$\begin{array}{lrrrrr}\begin{array}{l}\text { Question immediately preceding } \\ \text { competence block(a) }\end{array} & 10.9 & 13.3 & 13.1 & 12.7 & 12.2 \\ \begin{array}{l}\text { Competence block } \\ \quad \text { Importance (first item)(b) }\end{array} & \text { n.a. } & 9.7 & 6.4 & 8.3 & 7.8 \\ \quad \text { Required level (first item)(b) } & 11.7 & 9.7 & 6.7 & 8.8 & 8.0 \\ \quad \text { Own level (first item) } & 16.6 & 14.0 & 13.1 & 13.1 & 13.8 \\ \quad \text { Attention wanted (first item) } & \text { n.a. } & 14.0 & 13.5 & 13.5 & 13.8 \\ \text { Importance (last item)(b) } & \text { n.a. } & 21.2 & 15.5 & 12.4 & 12.9 \\ \quad \text { Required level (last item)(b) } & 15.5 & 21.2 & 15.8 & 12.7 & 13.1 \\ \text { Own level (last item) } & 19.7 & 25.0 & 21.6 & 17.0 & 18.6 \\ \quad \text { Attention wanted (last item) } & \text { n.a. } & 25.0 & 21.4 & 17.4 & 18.6 \\ \text { Question immediately following } & & & & & \\ \text { competence block(c) } & 16.8 & 22.9 & 19.8 & 15.3 & 16.9 \\ & & & & & \end{array}$

Notes:

(a) 'Grade' assigned to study program by respondent for didactical skills of lecturers

(b) Restricted to graduates in paid employment

(c) 'Looking back, if you could choose again, would you choose the same study program?'

More interesting for our purposes is the progression of the item non-response between the first and the last items in the competence block. Whereas the item non-response is similar at the start, by the end of the block substantial differences between the lists are apparent. The best list in this respect is Dublin list 3, in which no anchors were used, closely followed by list 4, containing the original $\mathrm{O}^{*} \mathrm{NET}$ anchors. The highest item non-response by far is seen for Dublin list 1, followed by list 2. The difference between list 1 and list 2 may be attributable to the less complicated layout of the latter list. There is no way of confirming this definitively, but this may suggest that the item non-response of list 3 and 4 - which share the complicated layout of list 1 - could be reduced even further. The regular list occupies an intermediate position. As predicted in Item non-response (null) hypothesis 3, there is little or no difference between the item non response to the importance and required level questions at any stage in any list. Finally, the last 
row of Table 1 shows that few of those who stopped responding to the competence items return to continue with the questionnaire afterwards.

In order to give a clearer picture of the development of item non-response, Table 2 shows the incremental change in item non-response per stage of the questionnaire. To avoid unnecessary cluttering, we limit the presentation of competence items to the dimension own level.

Table 2

Incremental change in item non-response at different stages

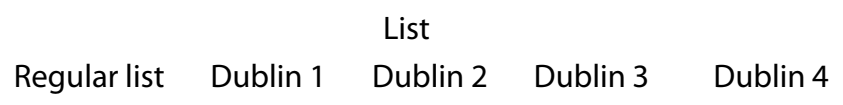

Question immediately preceding

competence block

10.9

13.3

13.1

12.7

12.2

Competence block

Own level (first item)

Own level (last item)

$+5.7$

$+0$

$+0.0$

$+0.4$

$+1.7$

Question immediately following

competence block

$+3.1+11.0$

$+8.6$

$+3.9$

$+4.8$

$\begin{array}{lllll}-2.9 & -2.1 & -1.8 & -1.7 & -1.7\end{array}$

Table 2 underscores the great impact of Dublin list 1, and to a lesser extent list 2 . Lists 3 and 4 show much less reduction in response. The regular list elicits much more of a 'blanket' non- response - almost $6 \%$ of graduates do not even start to answer it - but only a modest increase is seen as the list progresses.

The large difference between the lists is difficult to understand. Only one of the lists using anchors (list 4, with the original O*NET anchors) has a satisfactorily modest impact on response, but it is not immediately clear why this should be the case. In most respects list 4 is not inherently less complicated than list 1 , and is arguably more complicated than list 2, which separates the questions on own and required level. One possibility is that the $\mathrm{O}^{*} \mathrm{NET}$ anchors, which have been extensively tested (albeit among the US labour force rather than Dutch higher 
education graduates), make more sense to graduates than the hitherto untested new anchors. As we shall see however, in subsequent tests the $\mathrm{O}^{*} \mathrm{NET}$ anchors do not perform better than those in lists 1 and 2. The good news is that the item nonresponse for list 4 is lower than that for the regular list, and is only marginally higher than list 3 which uses no anchors. Although Item non-response (null) hypothesis 1 - which predicts no difference in item non-response between lists 1 and 2 on one hand and list 3 on the other - and Item non-response hypothesis 2 - which predicts less item non-response for lists 1 and 2 than for list 4 -are not supported by the data, the relatively low item non-response for list 4 suggests that scales using anchors are not inherently less likely to induce a response than scales without anchors. The large differences between the lists do however suggest that this is highly sensitive to the precise way in which the question is formulated and presented.

Despite this reassuring conclusion, one additional detail should be mentioned before moving on to a discussion of the distribution of answers to the competence questions. As mentioned above, the progression of non-response over the competence block is almost, but not quite, linear. Figure 1 shows the detailed nonresponse per item, again for the dimension own level. 


\section{Figure 1}

Item non-response per competence item (own level)

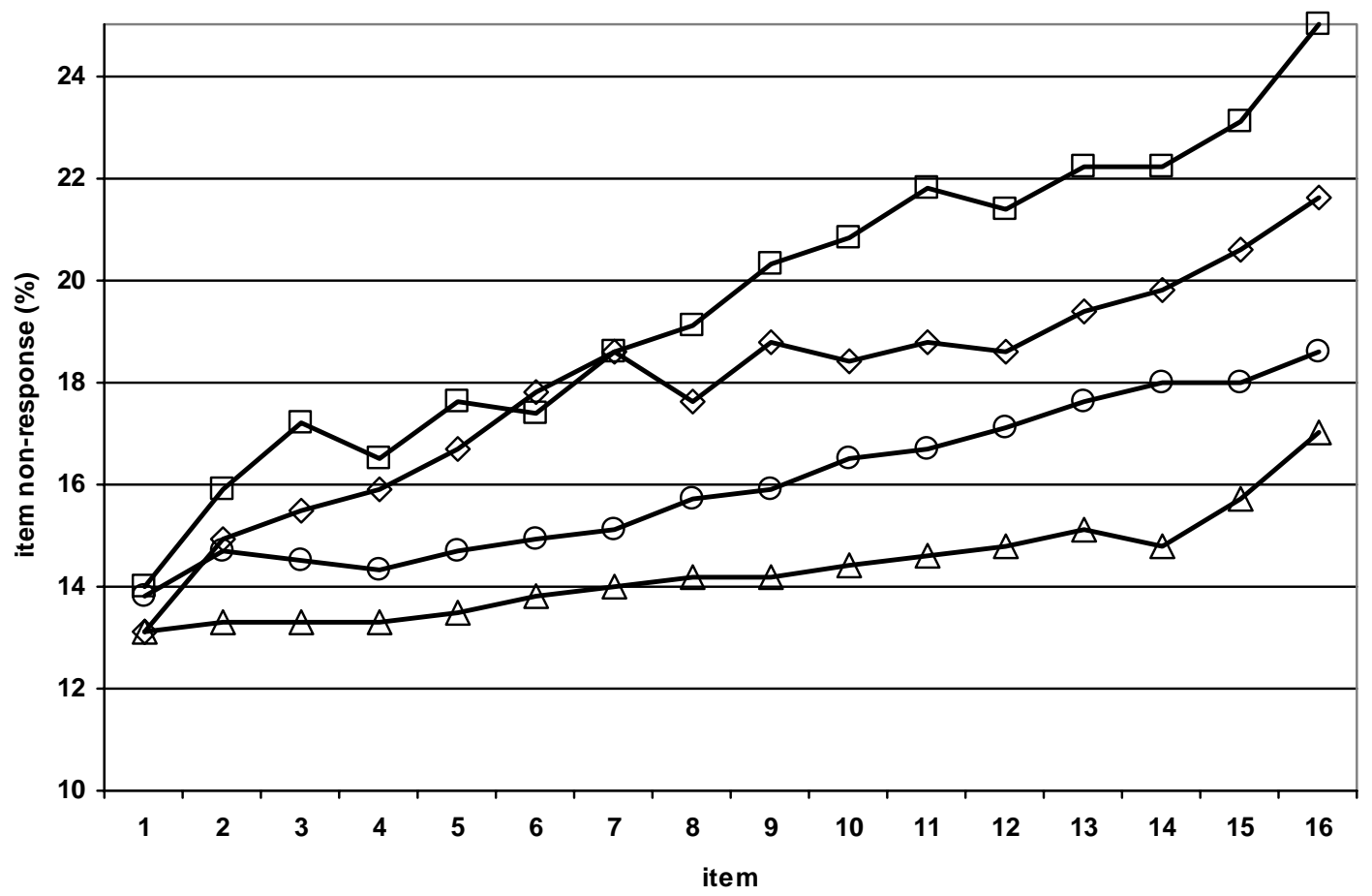

Dublin $1 \multimap$ Dublin $2 \multimap$ Dublin $3 \multimap$ Dublin 4

Figure 1 shows that the progression is indeed linear until about the 13th item, but that after that the rate of attrition appears to accelerate. This is especially the case for lists 1 and 4. This suggests that it would be unwise to seek to extend the length of the list beyond the current length, and that it may pay dividends to reduce the number of items.

\section{Distribution}

Tables 3 to 6 summarize some salient features of the distribution of answers to the competence questions. We look at the mean, the standard deviation, the kurtosis and the skewness of the distribution. To avoid cluttering the tables, for each list 
and each dimension (importance, required level, own level and attention) we present the minimum, maximum and mean item score of the measure in question.

Mean

Table 3 summarizes the results with respect to the means.

Table 3

Item means (minimum, maximum and overall mean per list)

List
Regularlist^ Dublin $1 \quad$ Dublin $2 \quad$ Dublin $3 \quad$ Dublin 4\#

\begin{tabular}{|c|c|c|c|c|c|c|}
\hline \multirow[t]{3}{*}{ Importance* } & Minimum & & 2.7 & 2.7 & 2.7 & 2.8 \\
\hline & Maximum & & 4.1 & 3.9 & 4.2 & 4.2 \\
\hline & Mean & & 3.5 & 3.3 & 3.6 & 3.5 \\
\hline \multirow[t]{3}{*}{ Required level* } & Minimum & 2.5 & 4.0 & 4.3 & 4.5 & 4.9 \\
\hline & Maximum & 4.3 & 6.3 & 6.0 & 6.5 & 6.4 \\
\hline & Mean & 3.7 & 5.0 & 5.0 & 5.7 & 5.4 \\
\hline \multirow[t]{3}{*}{ Own level } & Minimum & 3.2 & 4.4 & 4.7 & 5.2 & 4.7 \\
\hline & Maximum & 4.2 & 5.9 & 6.0 & 6.3 & 6.1 \\
\hline & Mean & 3.8 & 5.1 & 5.3 & 5.9 & 5.4 \\
\hline \multirow[t]{3}{*}{ Attention wanted } & Minimum & & 2.3 & 2.3 & 2.3 & 2.3 \\
\hline & Maximum & & 2.8 & 2.8 & 2.8 & 2.8 \\
\hline & Mean & & 2.6 & 2.5 & 2.5 & 2.5 \\
\hline
\end{tabular}

Notes:

*: Restricted to graduates in paid employment

$\wedge: 5$ point scales

\#: Required and own level based on 5 8-point items

One of the major concerns of the regular list without anchors is that, in the absence of a clear frame of reference, respondents would overestimate their own, and possibly their required, level of competence. A direct comparison with the regular list is difficult, because this list uses 5-point scales rather than 8-point 14 
scales. List 4 is also not really suitable for comparison, since only 5 of the 16 items use 5-point scales. However, a comparison between lists 1 and 2 on one hand with list 3 on the other hand, reveals that the use of anchors does reduce the mean level considerably, as predicted in Overestimation hypothesis 1. In contrast, on the dimensions importance and attention, there is almost no difference between the four lists. This finding provides a first indication that the use of anchors reduces self-overestimation.

\section{Standard deviation}

Table 4 summarizes the results for the standard deviations.

Table 4

Item standard deviation (minimum, maximum and overall mean per list)

\begin{tabular}{|c|c|c|c|c|c|c|}
\hline & & \multicolumn{5}{|c|}{ List } \\
\hline & & Regular list^ & Dublin 1 & Dublin 2 & Dublin 3 & Dublin 4\# \\
\hline \multirow[t]{3}{*}{ Importance* } & Minimum & & 0.8 & 0.8 & 0.8 & 0.8 \\
\hline & Maximum & & 1.0 & 1.0 & 1.1 & 1.0 \\
\hline & Mean & & 0.9 & 0.9 & 0.9 & 0.9 \\
\hline \multirow[t]{3}{*}{ Required level* } & Minimum & 0.7 & 1.3 & 1.3 & 1.2 & 1.2 \\
\hline & Maximum & 1.2 & 1.8 & 1.7 & 1.7 & 1.5 \\
\hline & Mean & 0.9 & 1.5 & 1.5 & 1.4 & 1.4 \\
\hline \multirow[t]{3}{*}{ Own level } & Minimum & 0.6 & 1.2 & 1.1 & 1.0 & 1.1 \\
\hline & Maximum & 1.0 & 1.6 & 1.6 & 1.3 & 1.4 \\
\hline & Mean & 0.7 & 1.4 & 1.3 & 1.1 & 1.2 \\
\hline \multirow[t]{3}{*}{ Attention wanted } & Minimum & & 0.5 & 0.5 & 0.5 & 0.5 \\
\hline & Maximum & & 0.7 & 0.7 & 0.7 & 0.7 \\
\hline & Mean & & 0.6 & 0.6 & 0.6 & 0.6 \\
\hline \multicolumn{7}{|c|}{ Notes: } \\
\hline \multicolumn{7}{|l|}{$\wedge: 5$ point scales } \\
\hline \#: Required and on & based or & -point items & & & & \\
\hline
\end{tabular}


Related to the above-mentioned issue of overestimation, a further argument for the use of anchors was that it would lead to a greater spread in answers. Again, the relevant comparison is between lists 1 and 2 on one hand and list 3 on the other. There seems to be a moderate increase in the standard deviation of own level, but only a rather slight increase for required level, providing at best only rather weak support for Distribution hypothesis 1 . However, the standard deviation for the latter is higher than that for the former in all cases, suggesting that this dimension is less sensitive to 'bunching' than own level is. We look in more detail at the form of the distribution in Tables 5 and 6.

\section{Kurtosis}

Table 5

Item kurtosis (minimum, maximum and overall mean per list)

\begin{tabular}{|c|c|c|c|c|c|c|}
\hline & & & & List & & \\
\hline & & Regular list^ $\wedge$ & Dublin 1 & Dublin 2 & Dublin 3 & Dublin 4\# \\
\hline Importance* & Minimum & & -0.6 & -0.6 & -0.7 & -0.6 \\
\hline & Maximum & & 0.6 & 0.6 & 0.6 & 1.1 \\
\hline & Mean & & -0.1 & -0.1 & -0.2 & 0.0 \\
\hline Required level* & Minimum & -0.9 & -0.9 & -0.8 & -0.5 & -0.5 \\
\hline & Maximum & 2.4 & 1.3 & 1.8 & 1.5 & 1.7 \\
\hline & Mean & 0.6 & 0.0 & 0.1 & 0.4 & 0.4 \\
\hline Own level & Minimum & -0.4 & -0.6 & -0.7 & 0.0 & -0.6 \\
\hline & Maximum & 1.2 & 1.7 & 0.5 & 1.6 & 0.4 \\
\hline & Mean & 0.0 & 0.0 & -0.2 & 0.5 & -0.2 \\
\hline Attention wanted & Minimum & & -0.6 & -0.6 & -0.4 & -0.7 \\
\hline & Maximum & & 3.4 & 2.0 & 3.3 & 1.7 \\
\hline & Mean & & 0.5 & 0.1 & 0.6 & 0.1 \\
\hline Notes: & & & & & & \\
\hline *: Restricted to g & baid e & ent & & & & \\
\hline$\wedge: 5$ point scales & & & & & & \\
\hline \#: Required and c & becto & int items & & & & \\
\hline
\end{tabular}


Table 5 summarizes the results for the kurtosis or peakedness of the distribution. A positive kurtosis means that the distribution is concentrated around a few values in the centre, while a negative kurtosis means that the distribution is broad. A zero kurtosis indicates a (more or less) normal distribution.

As predicted in Distribution hypothesis 1, Table 5 confirms that the own and required levels according to list 3 are clearly more peaked than those for lists 1 and 2. Curiously, attention is quite strongly peaked for lists 1 and 3, but scarcely at all for lists 2 and 4.

\section{Skewness}

Table 6

Item skewness (minimum, maximum and overall mean per list)

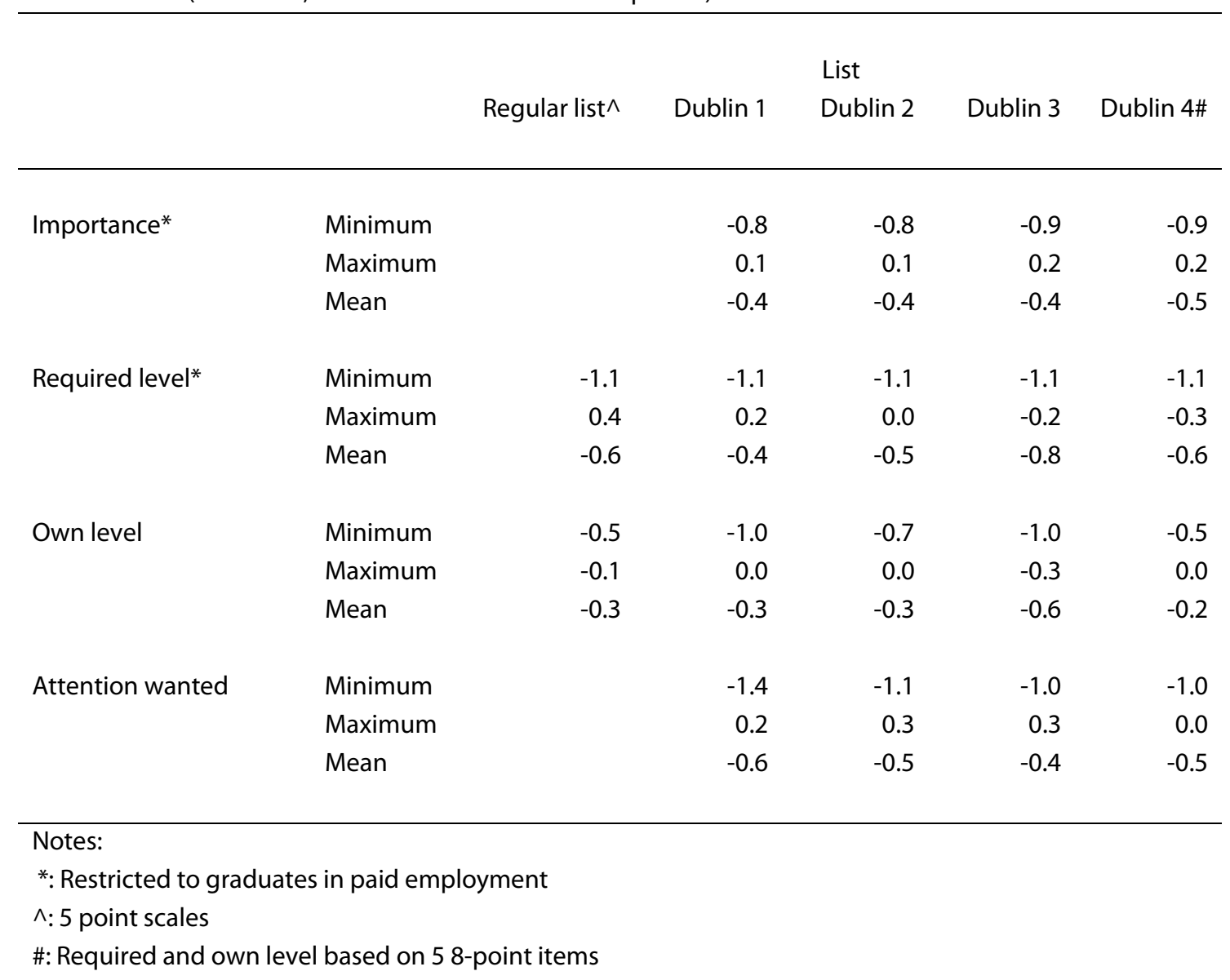


Finally, Table 6 shows the skewness of the distributions. Systematic overestimation of own and required competences would be expected to lead to a negative (left) skewing, in which most of the distribution is concentrated on the right, with a long tail on the left.

Although all the lists are at least somewhat skewed to the left, this is more pronounced for own and required level for list 3 than for lists 1 and 2. This is again consistent with the prediction of Distribution hypothesis 1 .

\section{Extreme values}

In the case of distributions that are heavily peaked and/or skewed, a major concern is that the extreme values will be over- or underrepresented. Tables 7 and 8 summarize the proportions of the distributions that are located in respectively the lowest and the highest possible values. A normally distributed pattern of answers on an 8 -point scale should contain around $2 \%$ of answers at both extremes.

Table 7 reveals that the lowest possible value is strongly represented in all Dublin Lists for required and particularly own level. Although a slightly higher percentage might have been desirable, this result is in a sense rather encouraging, since there was some concern that the deliberately truncated lists 1 and 2 might have led to left-censuring. ${ }^{1}$ The results offer little support for Distribution hypothesis 2, which

predicted that lists 1 and 2 would elicit more responses across the full range of possible values than list 3. The low percentage across the board render Distribution hypothesis 3, which predicted that lists 1 and 2 would be less sensitive to left censuring than list 3 , irrelevant.

1. The original O*NET items were formulated to apply across the entire range of capabilities of the work-force. Because the current questionnaire is aimed at higher education graduates, it was decided to truncate the lower end of the scale. 
Table 7

Percentage of respondents who answered the lowest possible value for an item (minimum, maximum and overall mean per list)

$\begin{array}{llll} & \text { List } & & \\ \text { Regular list^ Dublin } 1 & \text { Dublin } 2 & \text { Dublin } 3 & \text { Dublin } 4\end{array}$

\begin{tabular}{|c|c|c|c|c|c|c|}
\hline \multirow[t]{3}{*}{ Importance* } & Minimum & & 0.0 & 1.3 & 0.0 & 0.0 \\
\hline & Maximum & & 13.6 & 13.3 & 14.2 & 9.8 \\
\hline & Mean & & 3.3 & 4.3 & 2.5 & 3.0 \\
\hline \multirow[t]{3}{*}{ Required level* } & Minimum & 0.6 & 0.0 & 0.8 & 0.0 & 0.3 \\
\hline & Maximum & 27.9 & 4.8 & 5.0 & 6.1 & 3.2 \\
\hline & Mean & 3.1 & 2.1 & 2.6 & 1.3 & 1.5 \\
\hline \multirow[t]{3}{*}{ Own level } & Minimum & 0.0 & 0.0 & 0.0 & 0.0 & 0.0 \\
\hline & Maximum & 5.9 & 2.3 & 1.4 & 1.2 & 1.2 \\
\hline & Mean & 0.5 & 0.7 & 0.2 & 0.2 & 0.4 \\
\hline \multirow[t]{3}{*}{ Attention wanted } & Minimum & & 2.2 & 1.8 & 2.3 & 1.8 \\
\hline & Maximum & & 13.7 & 9.7 & 13.4 & 10.6 \\
\hline & Mean & & 6.1 & 4.7 & 6.5 & 5.3 \\
\hline
\end{tabular}

Notes:

*: Restricted to graduates in paid employment

$\wedge: 5$ point scales

Table 8 shows that the answers to own and required competences are slightly more concentrated in the highest possible value for list 3 than for lists 1 and 2. On average, all three lists are probably within an acceptable range. However, we see that at least 1 item shows a very high proportion (20.5\%) for required competences on list 3, while one or more items on lists 1 and 2 show a perhaps unacceptably low level. ${ }^{2}$ The results offer some support for Distribution hypothesis 3, which predicted that lists 1 and 2 would be less sensitive to right censuring than list 3 , but are

2. Closer inspections reveals that $20.5 \%$ of graduates answered the highest possible value to item 10 on list 3 (communication, general item), and $15.3 \%$ gave the maximum answer to item 13 (explaining information to others). The highest possible value was rarely used on item 1 in list 2 (field-specific knowledge, general item; $0.5 \%$ ) and item 16 in list 1 (learning strategy; 0.6\%). 
inconsistent with Distribution hypothesis 2, which predicted that lists 1 and 2 would elicit more responses across the full range of possible values than list 3 .

Table 8

Percentage of respondents who answered the highest possible value for an item (minimum, maximum and overall mean per list)

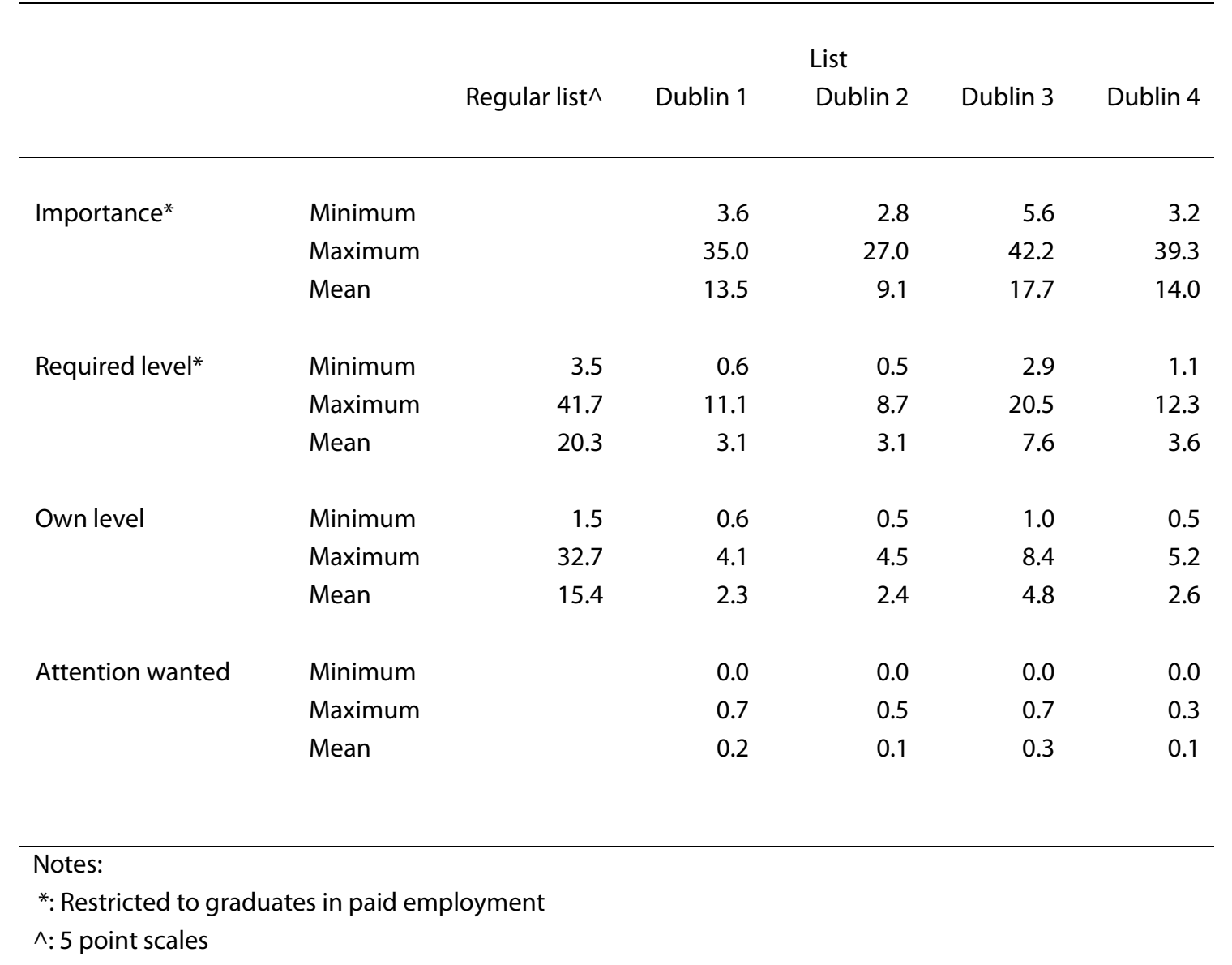

\section{Differentiation between categories}

\section{Differentiation between $\mathrm{HBO}$ and WO}

Although the results so far show a generally positive impact of anchors on the distribution of answers, a more important claim of this approach is that it differentiates better between relevant groups. The most salient distinction hereby is that between graduates of universities and $\mathrm{HBO}$ colleges. 


\begin{tabular}{|c|c|c|c|c|c|c|}
\hline & & Regular list^^ & Dublin 1 & $\begin{array}{c}\text { List } \\
\text { Dublin } 2\end{array}$ & Dublin 3 & Dublin 4 \\
\hline \multirow[t]{3}{*}{ Importance* } & Minimum & & -0.5 & -0.4 & -0.6 & -0.4 \\
\hline & Maximum & & 0.3 & 0.3 & 0.3 & 0.1 \\
\hline & Mean & & 0.0 & 0.0 & -0.1 & -0.2 \\
\hline \multirow[t]{3}{*}{ Required level* } & Minimum & -0.4 & -0.7 & -0.4 & -0.9 & -0.6 \\
\hline & Maximum & 0.2 & 0.9 & 0.7 & 0.3 & 0.1 \\
\hline & Mean & 0.0 & 0.1 & 0.1 & -0.2 & -0.2 \\
\hline \multirow[t]{3}{*}{ Own level } & Minimum & -0.1 & -0.5 & -0.3 & -0.5 & -0.6 \\
\hline & Maximum & 0.3 & 0.7 & 0.6 & 0.2 & 0.3 \\
\hline & Mean & 0.0 & 0.1 & 0.2 & -0.1 & 0.0 \\
\hline \multirow[t]{3}{*}{ Attention wanted } & Minimum & & -0.2 & -0.1 & -0.1 & -0.1 \\
\hline & Maximum & & 0.3 & 0.2 & 0.3 & 0.3 \\
\hline & Mean & & 0.0 & 0.0 & 0.1 & 0.0 \\
\hline
\end{tabular}

Notes:

*: Restricted to graduates in paid employment

$\wedge: 5$ point scales

There is disappointingly little difference between $\mathrm{HBO}$ and WO for own and required levels. The mean answers on own and required levels are slightly higher for WO on lists 1 and 2 than for the other lists, but the difference is minimal. These results clearly contradict the predictions in the weak and especially the strong version of Differentiation hypothesis 1 . Closer inspection reveals that there are items in these lists on which the difference is between a half and a whole point. It may be that a better selection of items would work better, but it should be 
remarked that even these differences fall far short of the 2 points difference that would be expected on the basis of the levels that were theoretically assigned. ${ }^{3}$

\section{Differentiation between study programs}

Another criterion for the items is that they should differentiate more between study programs. Tables 10 and 11 describe the between-program variance for items.

Table 10

Between-program variance for an item (minimum, maximum and overall mean per list)

\begin{tabular}{|c|c|c|c|c|c|c|}
\hline & & \multicolumn{5}{|c|}{ List } \\
\hline & & Regular list^^ & Dublin 1 & Dublin 2 & Dublin 3 & Dublin 4 \\
\hline \multirow[t]{3}{*}{ Importance* } & Minimum & & 0.000 & 0.000 & 0.000 & 0.000 \\
\hline & Maximum & & 0.152 & 0.281 & 0.223 & 0.024 \\
\hline & Mean & & 0.000 & 0.088 & 0.063 & 0.005 \\
\hline \multirow[t]{3}{*}{ Required level* } & Minimum & 0.000 & 0.000 & 0.000 & 0.000 & 0.000 \\
\hline & Maximum & 0.312 & 0.159 & 0.344 & 0.158 & 0.022 \\
\hline & Mean & 0.031 & 0.044 & 0.087 & 0.060 & 0.007 \\
\hline \multirow[t]{3}{*}{ Own level } & Minimum & 0.000 & 0.000 & 0.000 & 0.000 & 0.000 \\
\hline & Maximum & 0.079 & 0.182 & 0.376 & 0.149 & 0.060 \\
\hline & Mean & 0.015 & 0.057 & 0.146 & 0.042 & 0.011 \\
\hline \multirow[t]{3}{*}{ Attention wanted } & Minimum & & 0.000 & 0.000 & 0.000 & 0.000 \\
\hline & Maximum & & 0.199 & 0.190 & 0.096 & 0.031 \\
\hline & Mean & & 0.054 & 0.068 & 0.036 & 0.006 \\
\hline
\end{tabular}

Notes:

*: Restricted to graduates in paid employment

$\wedge: 5$ point scales

3. As a quick check of this expectation, several colleagues not involved in developing and/or testing the in-strument were asked to assess the items in lists 1 and 2 in terms of their clarity. When the difference be-tween HBO and university graduates (as well as other outcomes) is plotted these colleagues' assessment, it appears that items that are assessed as being more clearly formulated show more differentiation between university and HBO graduates. Clearer items also perform better in terms of the shape of the distribution and the percentage of variance that is located between study programs. 
Table 11

Between-program variance as percentage of all variance for an item (minimum, maximum and overall mean per list)

\begin{tabular}{|c|c|c|c|c|c|c|}
\hline & & \multicolumn{5}{|c|}{ List } \\
\hline & & Regular list^^ & Dublin 1 & Dublin 2 & Dublin 3 & Dublin 4 \\
\hline \multirow[t]{3}{*}{ Importance* } & Minimum & & 0.0 & 0.0 & 0.0 & 0.0 \\
\hline & Maximum & & 15.9 & 12.1 & 12.3 & 5.8 \\
\hline & Mean & & 0.0 & 3.9 & 3.1 & 1.2 \\
\hline \multirow[t]{3}{*}{ Required level* } & Minimum & 0.0 & 0.0 & 0.0 & 0.0 & 0.0 \\
\hline & Maximum & 19.6 & 14.4 & 13.2 & 9.0 & 5.8 \\
\hline & Mean & 3.1 & 4.5 & 3.3 & 3.3 & 1.8 \\
\hline \multirow[t]{3}{*}{ Own level } & Minimum & 0.0 & 0.0 & 0.0 & 0.0 & 0.0 \\
\hline & Maximum & 7.9 & 15.5 & 14.1 & 10.5 & 11.7 \\
\hline & Mean & 2.6 & 6.2 & 6.7 & 3.3 & 2.5 \\
\hline \multirow[t]{3}{*}{ Attention wanted } & Minimum & & 0.0 & 0.0 & 0.0 & 0.0 \\
\hline & Maximum & & 22.4 & 12.3 & 8.1 & 7.7 \\
\hline & Mean & & 6.3 & 4.2 & 3.1 & 1.5 \\
\hline
\end{tabular}

Notes:

*: Restricted to graduates in paid employment

$\wedge: 5$ point scales

Table 10 shows the absolute variance between study programs, and Table 11 the same variance as a percentage of all variance. Although the proportion of variance that is located at this level is quite modest in all the lists, lists 1 and 2 show around twice as large a proportion at that level than the other lists for the own level of competence. This result is consistent with the prediction in Differentiation hypothesis 2. However, these lists also show a relatively high degree of differentiation between programs for the dimension attention, which does not have anchors. There is less difference for the other dimensions, but this is to be expected. 


\section{Differentiation between occupations}

Table 12

Between-occupation variance for an item (minimum, maximum and overall mean per list)

List

$\begin{array}{lllll}\text { Regular list^ Dublin } 1 & \text { Dublin } 2 & \text { Dublin } 3 & \text { Dublin } 4\end{array}$

\begin{tabular}{|c|c|c|c|c|c|c|}
\hline \multicolumn{7}{|l|}{ Occupational level } \\
\hline \multirow[t]{3}{*}{ Importance* } & Minimum & & 0.000 & 0.000 & 0.000 & 0.000 \\
\hline & Maximum & & 0.739 & 0.580 & 0.066 & 0.192 \\
\hline & Mean & & 0.238 & 0.292 & 0.013 & 0.039 \\
\hline \multirow[t]{3}{*}{ Required level* } & Minimum & 0.000 & 0.000 & 0.000 & 0.000 & 0.000 \\
\hline & Maximum & 0.253 & 1.855 & 2.131 & 1.511 & 0.578 \\
\hline & Mean & 0.068 & 0.637 & 1.192 & 0.118 & 0.199 \\
\hline \multirow[t]{3}{*}{ Own level } & Minimum & 0.000 & 0.000 & 0.000 & 0.000 & 0.000 \\
\hline & Maximum & 0.014 & 0.205 & 0.042 & 0.131 & 0.061 \\
\hline & Mean & 0.001 & 0.030 & 0.010 & 0.005 & 0.010 \\
\hline \multirow[t]{3}{*}{ Attention wanted } & Minimum & & 0.000 & 0.000 & 0.000 & 0.000 \\
\hline & Maximum & & 0.015 & 0.004 & 0.022 & 0.016 \\
\hline & Mean & & 0.003 & 0.001 & 0.004 & 0.003 \\
\hline \multicolumn{7}{|l|}{ Occupational group } \\
\hline \multirow[t]{3}{*}{ Importance* } & Minimum & & 0.000 & 0.000 & 0.000 & 0.011 \\
\hline & Maximum & & 0.115 & 0.091 & 0.198 & 0.187 \\
\hline & Mean & & 0.038 & 0.043 & 0.052 & 0.093 \\
\hline \multirow[t]{3}{*}{ Required level* } & Minimum & 0.000 & 0.000 & 0.000 & 0.000 & 0.000 \\
\hline & Maximum & 0.312 & 0.323 & 0.233 & 0.323 & 0.248 \\
\hline & Mean & 0.031 & 0.070 & 0.072 & 0.098 & 0.133 \\
\hline \multirow[t]{3}{*}{ Own level } & Minimum & 0.000 & 0.000 & 0.000 & 0.000 & 0.000 \\
\hline & Maximum & 0.079 & 0.155 & 0.143 & 0.131 & 0.216 \\
\hline & Mean & 0.015 & 0.037 & 0.028 & 0.036 & 0.054 \\
\hline \multirow[t]{3}{*}{ Attention wanted } & Minimum & & 0.000 & 0.000 & 0.000 & 0.000 \\
\hline & Maximum & & 0.022 & 0.029 & 0.026 & 0.015 \\
\hline & Mean & & 0.007 & 0.006 & 0.007 & 0.003 \\
\hline
\end{tabular}

Notes:

*: Restricted to graduates in paid employment

$\wedge: 5$ point scales 
Table 13

Between-occupation variance as percentage of all variance for an item (minimum, maximum and overall mean per list)

\begin{tabular}{|c|c|c|c|c|c|c|}
\hline & & \multicolumn{5}{|c|}{ List } \\
\hline & & Regular list^ & Dublin 1 & Dublin 2 & Dublin 3 & Dublin 4 \\
\hline \multicolumn{7}{|l|}{ Occupational level } \\
\hline \multirow[t]{3}{*}{ Importance* } & Minimum & & 0.0 & 0.0 & 0.0 & 0.0 \\
\hline & Maximum & & 49.0 & 50.4 & 7.0 & 19.9 \\
\hline & Mean & & 20.1 & 26.4 & 1.5 & 4.2 \\
\hline \multirow[t]{3}{*}{ Required level* } & Minimum & 0.0 & 0.0 & 0.0 & 0.0 & 0.0 \\
\hline & Maximum & 29.2 & 50.3 & 52.4 & 43.8 & 28.2 \\
\hline & Mean & 7.7 & 19.4 & 36.5 & 3.8 & 10.5 \\
\hline \multirow[t]{3}{*}{ Own level } & Minimum & 0.0 & 0.0 & 0.0 & 0.0 & 0.0 \\
\hline & Maximum & 3.6 & 10.3 & 2.1 & 7.7 & 5.2 \\
\hline & Mean & 0.3 & 1.5 & 0.5 & 0.4 & 0.7 \\
\hline \multirow[t]{3}{*}{ Attention wanted } & Minimum & & 0.0 & 0.0 & 0.0 & 0.0 \\
\hline & Maximum & & 3.7 & 1.1 & 5.0 & 4.0 \\
\hline & Mean & & 0.7 & 0.2 & 0.9 & 0.8 \\
\hline \multicolumn{7}{|l|}{ Occupational group } \\
\hline \multirow[t]{3}{*}{ Importance* } & Minimum & & 0.0 & 0.0 & 0.0 & 1.3 \\
\hline & Maximum & & 11.9 & 8.1 & 18.4 & 23.9 \\
\hline & Mean & & 3.5 & 4.0 & 5.6 & 10.4 \\
\hline \multirow[t]{3}{*}{ Required level* } & Minimum & 0.0 & 0.0 & 0.0 & 0.0 & 0.0 \\
\hline & Maximum & 19.6 & 14.1 & 7.5 & 12.6 & 15.5 \\
\hline & Mean & 3.1 & 2.5 & 2.2 & 4.4 & 7.8 \\
\hline \multirow[t]{3}{*}{ Own level } & Minimum & 0.0 & 0.0 & 0.0 & 0.0 & 0.0 \\
\hline & Maximum & 7.9 & 7.1 & 7.0 & 8.2 & 15.3 \\
\hline & Mean & 2.6 & 1.8 & 1.5 & 2.7 & 4.2 \\
\hline \multirow[t]{3}{*}{ Attention wanted } & Minimum & & 0.0 & 0.0 & 0.0 & 0.0 \\
\hline & Maximum & & 4.4 & 8.0 & 5.9 & 3.6 \\
\hline & Mean & & 1.6 & 1.8 & 1.6 & 0.8 \\
\hline
\end{tabular}

Notes:

*: Restricted to graduates in paid employment

$\wedge: 5$ point scales 
Importance and required level should differentiate more between occupations than between study programs. Tables 12 and 13 show the variance between occupations for the items. In the case of occupations, it was useful to distinguish between occupational level (analogous to the university-HBO distinction for study programs) and, within those levels, the different occupational groups that may be distinguished. Variance at both levels is shown in Tables 12 and 13.

Table 12 shows the absolute variance between occupational levels and groups, and Table 13 the same variance as a percentage of all variance. As expected, there is generally more variance between occupations (both levels and groups) for importance and required level than for own level and attention wanted. In general the greatest variance in required level is between levels, but the variance between groups is also sizable. Lists 1 and 2 show the greatest variance between occupational levels, and lists 3 and 4 the greatest variance between occupational groups. All the Dublin lists show more variance than the regular list.

\section{Differentiation between jobs below and jobs on own educational level}

Table 14 shows the difference between graduates working in jobs requiring at least their own educational level and graduates in jobs requiring one level lower.

As predicted in the weak version of Differentiation hypothesis 3, there is more difference between the required level of those working at compared to below their own level for lists 1 and 2 (and list 4 as well) than for list 3 and the regular list. However, the differences fall far short of the 2 or (in the case of $\mathrm{HBO}$ graduates working at junior college level) 3 scale points difference between bachelors-level jobs and masters-level jobs as predicted in the strong version of this hypothesis. Further inspection of the data (not shown in the table) reveals the somewhat mysterious result that, according to all the lists, $\mathrm{HBO}$ graduates working at $\mathrm{HBO}$ level report a higher mean required level than university graduates working at the same level. 
Table 14

Item difference between graduates working in a job requiring at least their own level and graduates working one level lower (minimum, maximum and overall mean per list)

List

Regular Dublin $1 \quad$ Dublin $2 \quad$ Dublin $3 \quad$ Dublin 4 list^

\begin{tabular}{|c|c|c|c|c|c|c|c|}
\hline \multirow[t]{6}{*}{ Importance* } & \multirow[t]{3}{*}{ University } & \multicolumn{2}{|l|}{ Minimum } & -0.1 & 0.1 & 0.0 & 0.1 \\
\hline & & \multicolumn{2}{|l|}{ Maximum } & 0.8 & 0.7 & 0.4 & 0.7 \\
\hline & & \multicolumn{2}{|l|}{ Mean } & 0.2 & 0.4 & 0.2 & 0.4 \\
\hline & \multirow[t]{3}{*}{$\mathrm{HBO}$} & \multicolumn{2}{|l|}{ Minimum } & -0.1 & 0.3 & 0.0 & 0.3 \\
\hline & & \multicolumn{2}{|l|}{ Maximum } & 0.6 & 0.9 & 0.4 & 0.8 \\
\hline & & \multicolumn{2}{|l|}{ Mean } & 0.2 & 0.6 & 0.2 & 0.6 \\
\hline \multirow[t]{6}{*}{ Required level* } & \multirow[t]{3}{*}{ University } & Minimum & 0.0 & 0.0 & 0.4 & 0.1 & 0.1 \\
\hline & & Maximum & 0.7 & 1.4 & 1.2 & 0.6 & 1.0 \\
\hline & & Mean & 0.4 & 0.7 & 0.8 & 0.3 & 0.6 \\
\hline & \multirow[t]{3}{*}{$\mathrm{HBO}$} & Minimum & 0.1 & 0.2 & 0.8 & -0.1 & 0.4 \\
\hline & & Maximum & 0.8 & 1.0 & 1.4 & 0.8 & 1.0 \\
\hline & & Mean & 0.3 & 0.7 & 1.1 & 0.4 & 0.8 \\
\hline \multirow[t]{6}{*}{ Own level } & \multirow[t]{3}{*}{ University } & Minimum & -0.3 & 0.0 & 0.1 & -0.2 & -0.5 \\
\hline & & Maximum & 0.3 & 0.8 & 0.7 & 0.3 & 0.2 \\
\hline & & Mean & 0.1 & 0.4 & 0.4 & 0.1 & 0.0 \\
\hline & \multirow[t]{3}{*}{$\mathrm{HBO}$} & Minimum & -0.2 & -0.2 & 0.0 & -0.2 & -0.1 \\
\hline & & Maximum & 0.4 & 0.6 & 0.6 & 0.6 & 0.5 \\
\hline & & Mean & 0.0 & 0.3 & 0.3 & 0.2 & 0.1 \\
\hline \multirow{7}{*}{$\begin{array}{l}\text { Attention } \\
\text { wanted }\end{array}$} & & & & -0.2 & -0.3 & -0.1 & -0.2 \\
\hline & \multirow[t]{3}{*}{ University } & \multicolumn{6}{|l|}{ Minimum } \\
\hline & & \multicolumn{2}{|l|}{ Maximum } & 0.3 & 0.1 & 0.3 & 0.3 \\
\hline & & \multicolumn{2}{|l|}{ Mean } & 0.0 & -0.1 & 0.0 & 0.0 \\
\hline & \multirow[t]{3}{*}{$\mathrm{HBO}$} & \multicolumn{2}{|l|}{ Minimum } & -0.3 & -0.2 & -0.2 & -0.3 \\
\hline & & \multicolumn{2}{|l|}{ Maximum } & 0.3 & 0.2 & 0.2 & 0.0 \\
\hline & & \multicolumn{2}{|l|}{ Mean } & 0.0 & 0.0 & 0.0 & -0.2 \\
\hline
\end{tabular}

Notes:

*: Restricted to graduates in paid employment

$\wedge: 5$ point scales 


\section{Predictive validity}

We now turn to the predictive validity of the items. In total we looked at predictions of four dependent variables. For an assessment of the performance of own level and attention, we used as the dependent variables the graduates' assessment of their study program as a basis to start working and as a basis to develop competencies on the job. The explanatory variables are the own level, the proportion preferring more attention and the proportion preferring less attention. For an assessment of the performance of required level and importance, we used the dependent variables hourly wage and job satisfaction. The explanatory variables in that case are the required level/importance, the proportion reporting a shortage and the proportion reporting a surplus. Separate analyses were run for required level and importance. No control variables were included in the main analyses, but university/HBO sector, gender and age were included in subsequent analyses to allow comparison of the contribution to explained variance. To avoid cluttering the analyses, the competence items are clustered per Dublin descriptor.

\section{Study program as a basis for starting work}

Table 15 shows the results of the analysis of the graduates' assessment of the study program as a basis for starting work. Results that are significant at $10 \%$ level or better are marked in bold.

In terms of explained variance, list 1 performs best. However, it should be remarked that two of the significant coefficients show the opposite sign to what was expected. Descriptor 5 (learning abilities) is negatively correlated with the graduates' assessment of the program, and more attention preferred to descriptor 1 (knowledge and insight) is positively related to the assessment. However, such anomalies occur on most lists, and the regular list shows no significant effects. 


\begin{tabular}{|c|c|c|c|c|c|}
\hline & \multicolumn{5}{|c|}{ List } \\
\hline & Regular list^ $\wedge$ & Dublin 1 & Dublin 2 & Dublin 3 & Dublin 4 \\
\hline \multicolumn{6}{|l|}{ Own level } \\
\hline Descriptor 1 & 0.094 & 0.116 & 0.075 & 0.110 & 0.038 \\
\hline Descriptor 2 & -0.006 & 0.028 & -0.070 & 0.087 & 0.128 \\
\hline Descriptor 3 & 0.054 & 0.112 & 0.116 & 0.144 & 0.064 \\
\hline Descriptor 4 & 0.065 & 0.127 & -0.001 & -0.018 & 0.151 \\
\hline Descriptor 5 & 0.047 & -0.220 & -0.043 & -0.144 & -0.292 \\
\hline \multicolumn{6}{|l|}{ More attention wanted } \\
\hline Descriptor 1 & & 0.099 & -0.104 & -0.078 & 0.031 \\
\hline Descriptor 2 & & -0.165 & -0.047 & -0.010 & -0.157 \\
\hline Descriptor 3 & & -0.006 & -0.068 & -0.032 & 0.048 \\
\hline Descriptor 4 & & 0.023 & -0.021 & -0.014 & -0.069 \\
\hline Descriptor 5 & & -0.106 & -0.047 & 0.068 & 0.152 \\
\hline \multicolumn{6}{|l|}{ Less attention wanted } \\
\hline Descriptor 1 & & -0.002 & -0.022 & 0.027 & 0.112 \\
\hline Descriptor 2 & & -0.143 & -0.110 & -0.093 & -0.174 \\
\hline Descriptor 3 & & 0.053 & -0.053 & 0.064 & 0.003 \\
\hline Descriptor 4 & & -0.011 & -0.054 & -0.013 & 0.028 \\
\hline Descriptor 5 & & -0.107 & 0.108 & -0.032 & -0.008 \\
\hline \multicolumn{6}{|l|}{ Adjusted R-squared: } \\
\hline Own level competences & 0.019 & 0.041 & -0.002 & 0.030 & 0.035 \\
\hline Own level and attention & & 0.079 & 0.037 & 0.026 & 0.058 \\
\hline Competences and controls* & 0.089 & 0.132 & 0.112 & 0.111 & 0.098 \\
\hline Only controls* & 0.075 & 0.051 & 0.066 & 0.097 & 0.060 \\
\hline
\end{tabular}

Notes:

*: Restricted to graduates in paid employment

$\wedge: 5$ point scales

\section{Study program as a basis for developing competences}

Table 16 shows the results of the analysis of the graduates' assessment of the study program as a basis for developing competences. 
Regression coefficients, dependent variable graduates' assessment of program as basis to develop competences

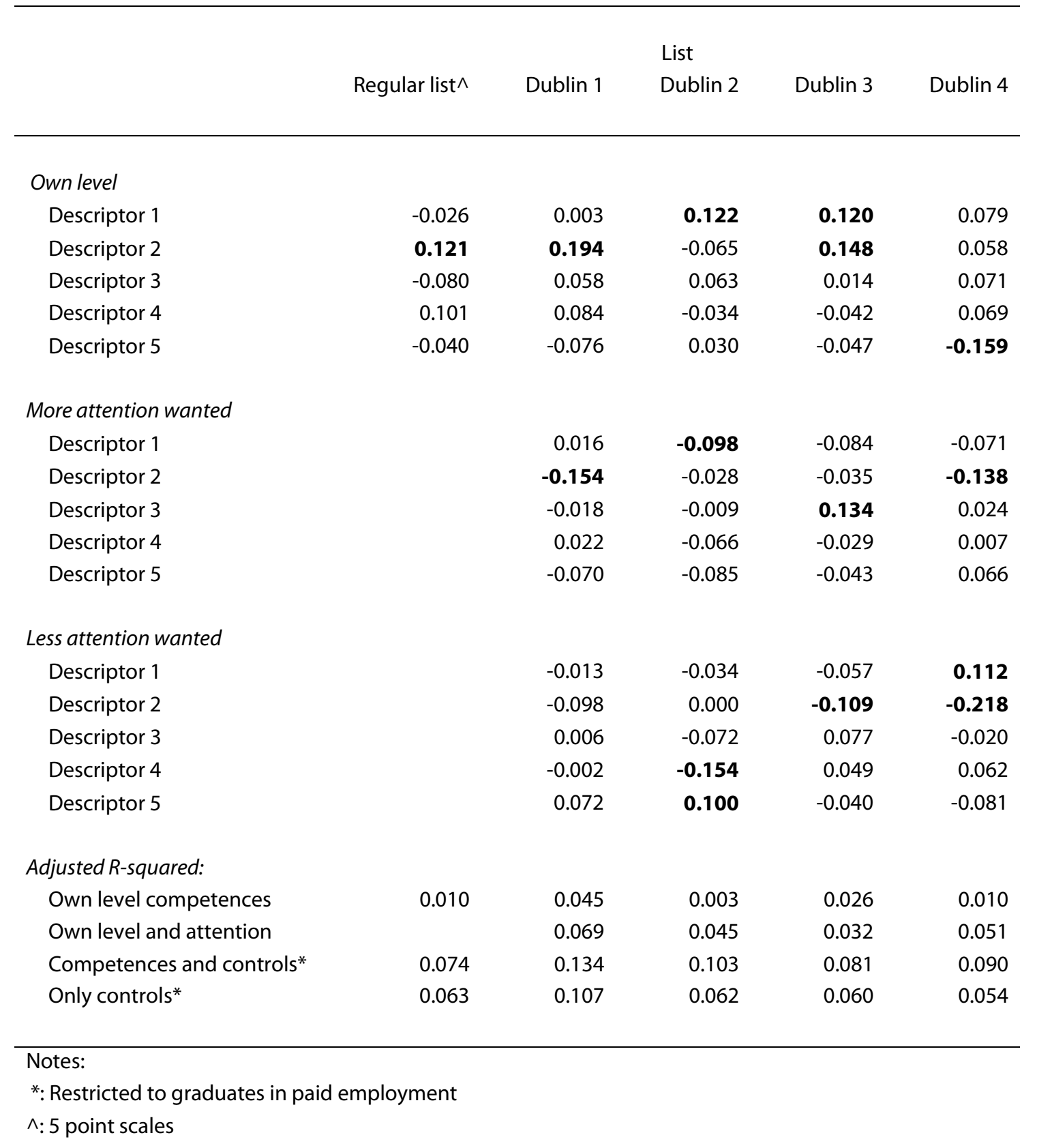

In terms of explained variance, list 1 again performs best, now without any significant unexpected effects. 


\section{Gross hourly wage}

Table 17 shows the results of the analysis of hourly wage, with required level, shortages and surpluses as predictors.

Table 17

Regression coefficients, dependent variable hourly wage (In)

\begin{tabular}{|c|c|c|c|c|c|}
\hline & \multicolumn{5}{|c|}{ List } \\
\hline & Regular list^ & Dublin 1 & Dublin 2 & Dublin 3 & Dublin 4 \\
\hline \multicolumn{6}{|l|}{ Required level } \\
\hline Descriptor 1 & -0.071 & 0.040 & -0.029 & 0.067 & 0.046 \\
\hline Descriptor 2 & 0.177 & 0.001 & -0.037 & 0.119 & -0.170 \\
\hline Descriptor 3 & 0.034 & 0.336 & 0.238 & 0.265 & 0.165 \\
\hline Descriptor 4 & 0.058 & -0.185 & -0.014 & -0.028 & 0.184 \\
\hline Descriptor 5 & 0.106 & 0.010 & 0.088 & -0.129 & -0.033 \\
\hline \multicolumn{6}{|l|}{ Shortage } \\
\hline Descriptor 1 & 0.068 & 0.006 & 0.003 & -0.060 & -0.051 \\
\hline Descriptor 2 & -0.078 & -0.154 & -0.091 & -0.011 & 0.020 \\
\hline Descriptor 3 & -0.041 & -0.036 & -0.128 & -0.021 & -0.086 \\
\hline Descriptor 4 & -0.038 & 0.018 & 0.047 & 0.032 & -0.132 \\
\hline Descriptor 5 & -0.060 & 0.098 & 0.015 & -0.083 & -0.067 \\
\hline \multicolumn{6}{|l|}{ Surplus } \\
\hline Descriptor 1 & 0.019 & -0.003 & 0.013 & 0.059 & -0.123 \\
\hline Descriptor 2 & -0.072 & 0.088 & -0.094 & 0.084 & -0.198 \\
\hline Descriptor 3 & 0.004 & 0.069 & 0.081 & 0.119 & 0.062 \\
\hline Descriptor 4 & -0.129 & -0.196 & -0.057 & -0.052 & 0.222 \\
\hline Descriptor 5 & 0.049 & -0.086 & 0.038 & -0.062 & -0.055 \\
\hline \multicolumn{6}{|l|}{ Adjusted R-squared: } \\
\hline Required level competences & 0.049 & 0.067 & 0.029 & 0.032 & 0.016 \\
\hline $\begin{array}{l}\text { Required level and } \\
\text { shortages/surpluses }\end{array}$ & 0.059 & 0.086 & 0.031 & 0.030 & 0.068 \\
\hline Competences and controls* & 0.292 & 0.361 & 0.280 & 0.280 & 0.331 \\
\hline Only controls* & 0.217 & 0.324 & 0.275 & 0.273 & 0.282 \\
\hline
\end{tabular}

Notes:

*: Restricted to graduates in paid employment

$\wedge: 5$ point scales 
In terms of explained variance, list 1 yet again performs best. Two effects are in an unexpected direction: descriptor 4 (communication) shows a negative effect, and a surplus of the same descriptor is penalized rather than rewarded.

Table 18

Regression coefficients, dependent variable hourly wage (In)

List

Dublin $1 \quad$ Dublin $2 \quad$ Dublin $3 \quad$ Dublin 4

\section{Importance}

Descriptor 1

Descriptor 2

Descriptor 3

Descriptor 4

Descriptor 5

Shortage

Descriptor 1

Descriptor 2

Descriptor 3

Descriptor 4

Descriptor 5

Surplus

Descriptor 1

Descriptor 2

Descriptor 3

Descriptor 4

Descriptor 5

Adjusted R-squared:

Importance competences

Importance and shortages/surpluses

Competences and controls*

Only controls*

$\begin{array}{rrrr}0.098 & -0.101 & -0.030 & 0.063 \\ -0.071 & -0.101 & \mathbf{0 . 1 6 1} & -0.075 \\ \mathbf{0 . 3 3 7} & 0.100 & \mathbf{0 . 2 4 2} & 0.122 \\ \mathbf{- 0 . 2 1 6} & 0.060 & -0.022 & 0.045 \\ -0.013 & 0.140 & -0.089 & 0.032\end{array}$

$\begin{array}{llll}0.093 & 0.030 & -0.058 & -0.005\end{array}$

$\begin{array}{llll}-0.028 & -\mathbf{0 . 1 2 3} & -0.014 & \mathbf{0 . 1 3 4}\end{array}$

$\begin{array}{llll}-\mathbf{0 . 2 5 8} & -0.091 & 0.027 & -0.107\end{array}$

$\begin{array}{llll}0.009 & -0.028 & 0.032 & \mathbf{- 0 . 1 7 0}\end{array}$

$\begin{array}{llll}0.042 & -0.118 & -0.058 & -0.071\end{array}$

$\begin{array}{rrrr}0.104 & -\mathbf{0 . 1 4 1} & 0.038 & -0.030 \\ 0.069 & -0.019 & 0.001 & -0.084 \\ 0.041 & \mathbf{0 . 1 3 3} & 0.126 & 0.021 \\ -0.071 & -0.109 & 0.004 & \mathbf{0 . 1 2 1} \\ \mathbf{- 0 . 1 4 3} & 0.017 & -0.059 & -0.092\end{array}$

$\begin{array}{llll}0.031 & 0.011 & 0.048 & 0.002 \\ 0.077 & 0.058 & 0.040 & 0.033 \\ 0.350 & 0.304 & 0.301 & 0.295 \\ 0.324 & 0.275 & 0.273 & 0.282\end{array}$

Notes:

*: Restricted to graduates in paid employment

$\wedge: 5$ point scales 
Table 18 shows the results of the analysis of hourly wage, now with importance, shortages and surpluses (based on importance) as predictors. In terms of explained variance, list 3 now performs best.

\section{Job satisfaction}

Table 19

Regression coefficients, dependent variable job satisfaction

List

$\begin{array}{lllll}\text { Regular list^ } & \text { Dublin } 1 & \text { Dublin } 2 & \text { Dublin } 3 & \text { Dublin } 4\end{array}$

\begin{tabular}{|c|c|c|c|c|c|}
\hline \multicolumn{6}{|l|}{ Required level } \\
\hline Descriptor 1 & -0.038 & 0.017 & 0.004 & 0.220 & 0.059 \\
\hline Descriptor 2 & 0.073 & 0.030 & 0.304 & -0.055 & 0.084 \\
\hline Descriptor 3 & 0.054 & 0.052 & -0.241 & 0.110 & 0.045 \\
\hline Descriptor 4 & 0.222 & -0.074 & 0.149 & 0.042 & -0.003 \\
\hline Descriptor 5 & 0.029 & 0.056 & -0.008 & -0.067 & 0.076 \\
\hline \multicolumn{6}{|l|}{ Shortage } \\
\hline Descriptor 1 & -0.040 & -0.028 & -0.018 & -0.118 & -0.037 \\
\hline Descriptor 2 & -0.017 & 0.029 & -0.054 & 0.000 & -0.060 \\
\hline Descriptor 3 & 0.013 & 0.053 & 0.080 & 0.021 & 0.103 \\
\hline Descriptor 4 & 0.036 & -0.034 & -0.086 & 0.005 & -0.049 \\
\hline Descriptor 5 & 0.104 & -0.036 & -0.026 & -0.022 & -0.035 \\
\hline \multicolumn{6}{|l|}{ Surplus } \\
\hline Descriptor 1 & -0.073 & -0.018 & -0.003 & -0.042 & -0.154 \\
\hline Descriptor 2 & -0.054 & -0.149 & -0.074 & -0.073 & -0.155 \\
\hline Descriptor 3 & -0.021 & 0.054 & -0.076 & -0.053 & 0.171 \\
\hline Descriptor 4 & -0.113 & -0.176 & 0.019 & 0.144 & 0.052 \\
\hline Descriptor 5 & 0.152 & -0.028 & -0.111 & -0.079 & -0.148 \\
\hline \multicolumn{6}{|l|}{ Adjusted R-squared: } \\
\hline Required level competences & 0.177 & 0.023 & 0.104 & 0.060 & 0.077 \\
\hline Required level and shortages/surpluses & 0.222 & 0.056 & 0.112 & 0.057 & 0.109 \\
\hline Competences and controls* & 0.220 & 0.053 & 0.125 & 0.091 & 0.119 \\
\hline Only controls* & 0.009 & 0.013 & -0.003 & 0.012 & -0.006 \\
\hline
\end{tabular}

Notes:

*: Restricted to graduates in paid employment

$\wedge: 5$ point scales 
Table 19 shows the results of the analysis of job satisfaction, with required level, shortages and surpluses as predictors. In terms of explained variance, the regular list performs best. Of the Dublin lists, list 2 shows the greatest explained variance, although this is portly based on an unexpected negative effect of descriptor 3 (judgement).

\section{Table 20}

Regression coefficients, dependent variable job satisfaction

\begin{tabular}{|c|c|c|}
\hline & List & \\
\hline Dublin 1 & Dublin 2 & Dublin 3 \\
\hline
\end{tabular}

\section{Importance}

Descriptor 1

Descriptor 2

Descriptor 3

Descriptor 4

Descriptor 5

\section{Shortage}

Descriptor 1

Descriptor 2

Descriptor 3

Descriptor 4

Descriptor 5

\section{Surplus}

Descriptor 1

Descriptor 2

Descriptor 3

Descriptor 4

Descriptor 5

Adjusted R-squared: Importance competences Importance and shortages/ surpluses Competences and controls* Only controls*

$\begin{array}{rrrr}\mathbf{0 . 1 6 6} & 0.015 & \mathbf{0 . 1 5 4} & \mathbf{0 . 1 8 0} \\ 0.068 & \mathbf{0 . 2 4 6} & 0.060 & \mathbf{0 . 1 7 4} \\ 0.051 & \mathbf{- 0 . 2 0 0} & 0.035 & -0.097 \\ -0.092 & \mathbf{0 . 1 5 4} & 0.017 & 0.121 \\ -0.074 & 0.008 & 0.000 & -0.117\end{array}$

$\begin{array}{rrrr}-0.043 & 0.003 & 0.030 & 0.072 \\ 0.112 & -\mathbf{0 . 1 2 5} & -0.055 & -0.014 \\ -0.071 & 0.010 & -0.018 & 0.037 \\ -0.026 & -0.021 & 0.022 & -\mathbf{0 . 1 4 9} \\ -0.010 & 0.046 & -0.053 & 0.039\end{array}$

$\begin{array}{rrrr}0.005 & -0.108 & -\mathbf{0 . 1 5 8} & \mathbf{- 0 . 1 4 4} \\ \mathbf{- 0 . 1 4 8} & -0.127 & 0.020 & -0.005 \\ 0.031 & -0.020 & -0.096 & -0.104 \\ -0.114 & 0.035 & 0.016 & -0.023 \\ -0.035 & -0.010 & 0.032 & 0.006\end{array}$

$\begin{array}{rrrr}0.043 & 0.089 & 0.080 & 0.112 \\ 0.060 & 0.096 & 0.076 & 0.121 \\ 0.072 & 0.117 & 0.103 & 0.123 \\ 0.013 & -0.003 & 0.012 & -0.006\end{array}$

\section{Notes:}

*: Restricted to graduates in paid employment

$\wedge: 5$ point scales 
Table 20 shows the results of the analysis of job satisfaction, now with importance, shortages and surpluses (based on importance) as predictors.

List 4 explains slightly more variance than lists 2 and 3, and substantially more than list 1.

\section{Required level versus importance}

An important question is whether the question on required level conveys significantly other information than importance. Table 21 shows the correlations between these variables.

Table 21

Correlations between importance and required level per item

\begin{tabular}{rrrrr}
\hline item & Dublin 1 & Dublin 2 & Dublin 3 & Dublin 4 \\
& & & & \\
\hline 1 & 0.654 & 0.660 & 0.698 & 0.634 \\
2 & 0.525 & 0.698 & 0.776 & 0.683 \\
3 & 0.680 & 0.742 & 0.828 & 0.709 \\
4 & 0.589 & 0.679 & 0.745 & 0.689 \\
5 & 0.674 & 0.749 & 0.765 & 0.658 \\
6 & 0.722 & 0.811 & 0.831 & 0.772 \\
7 & 0.722 & 0.761 & 0.780 & 0.774 \\
8 & 0.669 & 0.718 & 0.800 & 0.722 \\
9 & 0.727 & 0.779 & 0.808 & 0.726 \\
10 & 0.599 & 0.685 & 0.745 & 0.632 \\
11 & 0.777 & 0.788 & 0.825 & 0.761 \\
12 & 0.707 & 0.766 & 0.829 & 0.713 \\
13 & 0.611 & 0.681 & 0.790 & 0.637 \\
14 & 0.691 & 0.730 & 0.808 & 0.661 \\
15 & 0.700 & 0.798 & 0.845 & 0.681 \\
16 & 0.782 & 0.757 & 0.872 & 0.809 \\
& & & & \\
\hline
\end{tabular}


The two dimensions appear to be highly correlated for all 4 lists and all items. What is striking is that the correlations are without exception the highest for list 3 , in which a fixed scale was used rather than anchor points.

A related issue is the extent to which discrepancies between own and required level convey different information than discrepancies between (standardized) importance and (standardized) own level. Table 22 shows the correlations.

Table 22

Correlations between discrepancies based on importance and required level per item

\begin{tabular}{rrrrr}
\hline item & Dublin 1 & Dublin 2 & Dublin 3 & Dublin 4 \\
& & & & \\
1 & & & & 0.704 \\
2 & 0.713 & 0.684 & 0.656 & 0.631 \\
3 & 0.563 & 0.701 & 0.675 & 0.645 \\
4 & 0.641 & 0.702 & 0.722 & 0.688 \\
5 & 0.641 & 0.731 & 0.676 & 0.707 \\
6 & 0.655 & 0.709 & 0.691 & 0.701 \\
7 & 0.655 & 0.770 & 0.711 & 0.701 \\
8 & 0.691 & 0.712 & 0.638 & 0.677 \\
9 & 0.611 & 0.711 & 0.754 & 0.669 \\
10 & 0.695 & 0.764 & 0.721 & 0.717 \\
11 & 0.612 & 0.706 & 0.746 & 0.703 \\
12 & 0.728 & 0.774 & 0.804 & 0.607 \\
13 & 0.634 & 0.719 & 0.752 & 0.609 \\
14 & 0.561 & 0.697 & 0.682 & 0.755 \\
15 & 0.687 & 0.726 & 0.789 & 0.729 \\
16 & 0.666 & 0.812 & 0.825 & 0.809 \\
\hline
\end{tabular}

Again, the correlations are very strong. With the exception of item 1, on which list 1 shows the highest correlations, the highest correlations are seen in lists 2 or 3 .

More important for an assessment of the relative value of the two kinds of discrepancies is to see how the outcomes are related to summarizing measures of utilization and shortages of competences. Table 23 shows the correlations between the mean proportion of shortages (a shortage is defined as a case where the own 
level is at least two points lower than the required level/importance) and the mean proportion of surpluses (a surplus is defined as a case where the own level is at least two points higher than the required level/importance) on one hand and the degree to which one's capacities are utilized at work and the degree to which one's capacities fall short of what is required at work on the other hand.

Table 23

Correlations between discrepancies and summarizing measures of shortages and utilization*

\begin{tabular}{|c|c|c|c|c|c|c|}
\hline & & $\begin{array}{r}\text { Regular } \\
\text { list^} \wedge\end{array}$ & Dublin 1 & $\begin{array}{c}\text { List } \\
\text { Dublin } 2\end{array}$ & Dublin 3 & Dublin 4 \\
\hline \multirow[t]{2}{*}{ Utilization } & shortage based on required level & 0.055 & 0.088 & 0.105 & 0.012 & -0.042 \\
\hline & surplus based on required level & -0.472 & -0.411 & -0.455 & -0.184 & -0.418 \\
\hline \multirow[t]{2}{*}{ Utilization } & shortage based on importance & & 0.068 & 0.091 & -0.012 & 0.031 \\
\hline & surplus based on importance & & -0.356 & -0.431 & -0.208 & -0.356 \\
\hline \multirow[t]{2}{*}{ Shortfall } & shortage based on required level & 0.225 & 0.291 & 0.221 & 0.242 & 0.227 \\
\hline & surplus based on required level & -0.225 & -0.271 & -0.158 & -0.167 & -0.306 \\
\hline \multirow[t]{2}{*}{ Shortfall } & shortage based on importance & & 0.227 & 0.229 & 0.191 & 0.132 \\
\hline & surplus based on importance & & -0.269 & -0.174 & -0.162 & -0.292 \\
\hline Notes: & & & & & & \\
\hline $\begin{array}{l}*: \text { Restrict } \\
\wedge: 5 \text { point }\end{array}$ & graduates in paid employment & & & & & \\
\hline
\end{tabular}

As we would expect, the overall measure of utilization is more strongly related to surpluses than to shortages. Interestingly, when based on required level, the strongest correlation is seen for the regular list. Lists 1, 2 and 4 also show strong correlations, but the correlation is quite weak for list 3, in which no anchors were used. In fact, list 3 is the most pure comparison, since it is practically identical to the other lists in other respects, while the regular list is different in more ways. A comparison with the results based on importance shows that - again with the exception of list 3 - the measures based on required level perform better. The differences are however quite modest. 
Turning to the correlations with shortfall, we expected this to be most closely related to shortages. There are however moderately high correlations with both shortages and surpluses. List 1 performs somewhat better than the other lists. A comparison with the correlations based on importance again shows only rather modest differences, and even a slight improvement for list 2 .

\section{General versus specific items}

The basic idea of using anchors is that these will provide an objective frame of reference against which all respondents can evaluate their competence levels. If anchors indeed fulfil this role, one would expect those items that contain anchors that refer to specific, recognizable tasks or actions to perform better than items that contain more generally formulated anchors. Each of the 5 Dublin descriptors have been indicated in the questionnaire (lists 1,2 and 4) by a single item with general anchors (e.g. knowledge of basic principles in your area of study or work), followed by two or three items with specific anchors (e.g. design new measures for reducing the level of sick leave in a firm). Since the general and specific items are intended to measure the same underlying concepts, we can compare the performance of these items in several respects.

In this section we look at the distributional characteristics, the degree of differentiation between relevant subgroups, and the predictive validity of general versus specific items. The main focus is on the items in lists 1 and 2, since list 3 contains no anchors at all, and the varying number of scale points for items in list 4 render such a comparison impracticable. In addition, only the performance of questions pertaining to own and required level are directly relevant, since the questions on importance and attention also contain no anchors. However, in performing the test, we need to keep in mind that, although the general and specific items purport to measure the same underlying concepts, the concrete substance of the items is different. It is possible that an observed difference is due not to the different nature of the anchors, but to the different substance of the item 
in question. To control for this, we also present the results for list 3 (which contain the same items but without anchors). If it is specific anchors that leads to better performance, we should see a difference for lists 1 and 2, but not for list 3 .

Tables 24 and 25 contain the key distributional characteristics of general versus specific items. To make it easier to see the difference between general and specific items, a difference score is presented. ${ }^{4}$ A positive difference means that general items score higher on average than specific items on the measure in question, a negative score that the reverse is true.

\section{Table 24}

Item means and standard deviations, mean of general versus specific items

\begin{tabular}{|c|c|c|c|c|c|c|c|}
\hline & & \multicolumn{3}{|c|}{ mean } & \multicolumn{3}{|c|}{ standard deviation } \\
\hline & & Dublin 1 & Dublin 2 & Dublin 3 & Dublin 1 & Dublin 2 & Dublin 3 \\
\hline \multirow[t]{3}{*}{ Required level* } & General items & 5.4 & 5.3 & 5.9 & 1.4 & 1.4 & 1.3 \\
\hline & Specific items & 4.9 & 4.9 & 5.7 & 1.6 & 1.6 & 1.5 \\
\hline & Difference & 0.5 & 0.4 & 0.2 & -0.1 & -0.1 & -0.1 \\
\hline \multirow[t]{3}{*}{ Own level } & General items & 5.3 & 5.5 & 6.0 & 1.3 & 1.2 & 1.1 \\
\hline & Specific items & 5.0 & 5.3 & 5.9 & 1.4 & 1.4 & 1.1 \\
\hline & Difference & 0.3 & 0.2 & 0.1 & -0.1 & -0.1 & -0.1 \\
\hline
\end{tabular}

*: Restricted to graduates in paid employment

Overestimation hypothesis 1 predicted that specific anchors would reduce the tendency of respondents to overestimate their own abilities. The first three columns of Table 24 provide some support for this hypothesis. This is especially true for required level, but also to some extent for own level. A difference is also observed for list 3 , suggesting that some of the difference is due to differences in substance, but these differences are quite a lot smaller, suggesting that using specific anchors does help reduce self-overestimation.

4. Because of rounding errors, the difference deviates from a simple subtraction of the general and specific scores as presented. The presented difference is a more accurate reflection of the actual difference. 
In distribution hypothesis 4, it was predicted that items containing specific anchors would show better distributional characteristics than items containing general anchors. More concretely, we would hope for a greater variance in answers (indicated by the standard deviation, see the last three columns of Table 24), and a distribution that is less peaked and/or skewed (indicated by the kurtosis and skewness as presented in Table 25).

Table 25

Item kurtosis and skewness, mean of general versus specific items

\begin{tabular}{|c|c|c|c|c|c|c|c|}
\hline & & \multicolumn{3}{|c|}{ Kurtosis } & \multicolumn{3}{|c|}{ Skewness } \\
\hline & & Dublin 1 & Dublin 2 & Dublin 3 & Dublin 1 & Dublin 2 & Dublin 3 \\
\hline \multirow[t]{3}{*}{ Required level* } & General items & 0.4 & 0.5 & 0.7 & -0.7 & -0.7 & -0.9 \\
\hline & Specific items & -0.2 & -0.2 & 0.3 & -0.3 & -0.4 & -0.7 \\
\hline & Difference & 0.6 & 0.7 & 0.4 & -0.3 & -0.3 & -0.1 \\
\hline \multirow[t]{3}{*}{ Own level } & General items & 0.3 & -0.1 & 0.7 & -0.4 & -0.4 & -0.7 \\
\hline & Specific items & -0.2 & -0.3 & 0.3 & -0.3 & -0.3 & -0.6 \\
\hline & Difference & 0.5 & 0.2 & 0.3 & -0.1 & -0.1 & -0.1 \\
\hline
\end{tabular}

*: Restricted to graduates in paid employment

The results in terms of distributional characteristics are mixed. Although specific items show a slightly greater standard deviation than general items, this applies as well to the items in list 3. There is little reason to believe that this (in any case very small) difference is due to the anchors. Looking at the kurtosis and skewness, it seems that specific items are less peaked (in fact even somewhat flatter than a normal distribution), and less skewed than general items. Some of these differences is also seen in list 3, suggesting that it is partly due to the substance of the items, but the greatest difference is seen in lists 1 and 2, suggesting that the specific items contribute to this effect.

Differentiation hypothesis 5 predicts that specific items will differentiate more between educational and occupational levels and fields than general items. To test 
this hypothesis, Tables 26 to 28 show the mean of items differences between educational levels, and the program-level and occupation-level variance, for general versus specific items.

Table 26

Item difference between university and HBO graduates, mean of general versus specific items

\begin{tabular}{llccc}
\hline & & & \\
& & List & \\
& & Dublin 1 & Dublin 2 & Dublin 3 \\
\hline \multirow{2}{*}{ Required level $^{*}$} & General items & 0.1 & 0.1 & -0.2 \\
& Specific items & 0.2 & 0.2 & -0.1 \\
& Difference & 0.0 & 0.0 & 0.0 \\
\multirow{5}{*}{ Own level } & General items & & & -0.1 \\
& Specific items & 0.2 & 0.2 & -0.1 \\
& Difference & 0.2 & 0.2 & 0.0 \\
& & 0.0 & 0.0 & \\
\hline
\end{tabular}

*: Restricted to graduates in paid employment

For both general and specific items, there is virtually no difference in mean scores between university and HBO graduates. Using specific anchors does not give rise to a clearer distinction between levels of higher education.

At first sight, the results presented in Table 27 seem encouraging. Specific items show more between-program variance, mainly for required level, but also for own level. However, this is also the case for list 3. There is little reason to believe that these differences are due to the nature of the anchors, and more reason to believe that they reflect substantive differences between the items. 
Table 27

Between-program variance for an item in absolute terms and as percentage of total item variance, mean of general versus specific items

Absolute between-program variance

Dublin $1 \quad$ Dublin 2 Dublin 3
$\%$ of total variance

Dublin 1 Dublin 2 Dublin 3

\begin{tabular}{llllllll}
\hline Required & & & & & & & \\
level* $^{*}$ & General items & 0.009 & 0.033 & 0.015 & 1.2 & 1.5 & 1.0 \\
& Specific items & 0.060 & 0.111 & 0.080 & 6.0 & 4.2 & 4.4 \\
& Difference & -0.050 & -0.079 & -0.065 & -4.8 & -2.7 & -3.4 \\
& & & & & & & \\
Own level & General items & 0.030 & 0.126 & 0.027 & 3.8 & 6.9 & 2.5 \\
& Specific items & 0.070 & 0.155 & 0.049 & 7.2 & 6.6 & 3.6 \\
& Difference & -0.040 & -0.029 & -0.022 & -3.5 & 0.4 & -1.1 \\
& & & & & & & \\
\hline
\end{tabular}

*: Restricted to graduates in paid employment

The results presented in Table 28 also fail to provide convincing support for distributional hypothesis 5 . The differences are sometimes in the reverse direction and when the expected differences show up, they are also seen in list 3. 
Between-occupation variance for an item in absolute terms and as percentage of total item variance, mean of general versus specific items

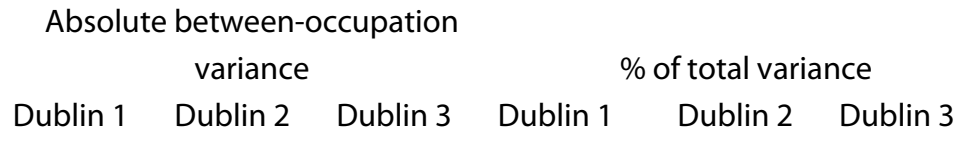

\begin{tabular}{|c|c|c|c|c|c|c|c|}
\hline \multicolumn{8}{|c|}{ Occupational level } \\
\hline \multirow[t]{3}{*}{ Required level* } & General items & 0.678 & 1.222 & 0.027 & 19.3 & 40.0 & 1.4 \\
\hline & Specific items & 0.618 & 1.178 & 0.160 & 19.5 & 35.0 & 4.9 \\
\hline & Difference & 0.060 & 0.044 & -0.133 & -0.2 & 5.0 & -3.6 \\
\hline \multirow[t]{3}{*}{ Own level } & General items & 0.001 & 0.000 & 0.005 & 0.1 & 0.0 & 0.5 \\
\hline & Specific items & 0.043 & 0.015 & 0.006 & 2.1 & 0.8 & 0.4 \\
\hline & Difference & -0.042 & -0.015 & -0.001 & -2.0 & -0.8 & 0.1 \\
\hline \multicolumn{8}{|c|}{ Occupational group } \\
\hline \multirow[t]{3}{*}{ Required level ${ }^{*}$} & General items & 0.068 & 0.034 & 0.048 & 3.0 & 1.1 & 2.8 \\
\hline & Specific items & 0.071 & 0.089 & 0.121 & 2.3 & 2.7 & 5.1 \\
\hline & Difference & -0.002 & -0.055 & -0.073 & 0.7 & -1.7 & -2.3 \\
\hline \multirow[t]{3}{*}{ Own level } & General items & 0.013 & 0.000 & 0.015 & 0.8 & 0.0 & 1.3 \\
\hline & Specific items & 0.048 & 0.041 & 0.045 & 2.2 & 2.2 & 3.3 \\
\hline & Difference & -0.034 & -0.041 & -0.031 & -1.4 & -2.2 & -2.0 \\
\hline
\end{tabular}

*: Restricted to graduates in paid employment

Prediction hypothesis 3 predicted that specific items will be better predictors of educational and labour market outcomes than general items. To test this hypothesis, separate regression analyses were run using the general and the mean of the specific items used to indicate each of the five Dublin descriptors. The results are summarized in Tables 29 and 30. Table 29 shows the regression coefficients of the indicator of own level for each of the Dublin descriptors, as predictors of the graduates' assessment of their study program as basis for starting work and for developing competences. Also included were dummies indicating that more attention was desired, and dummies indicating that less attention was desired for 
each of the descriptors. The coefficients for these dummies has been omitted for the sake of brevity, but can be obtained on request from the authors.

\section{Table 29}

Regression coefficients, dependent variables graduates' assessment of program as basis to start working and as a basis to develop competences, general versus specific items

\begin{tabular}{|c|c|c|c|c|c|c|c|}
\hline & & \multicolumn{3}{|c|}{ Basis to start working } & \multicolumn{3}{|c|}{ Basis to develop competences } \\
\hline & & Dublin 1 & Dublin 2 & Dublin 3 & Dublin 1 & Dublin 2 & Dublin 3 \\
\hline \multirow[t]{3}{*}{ Descriptor 1} & General items & 0.045 & 0.055 & 0.049 & 0.014 & 0.102 & -0.052 \\
\hline & Specific items & 0.115 & 0.063 & 0.089 & 0.040 & 0.042 & 0.164 \\
\hline & Difference & -0.07 & -0.008 & -0.04 & -0.026 & 0.06 & -0.216 \\
\hline \multirow[t]{3}{*}{ Descriptor 2} & General items & 0.088 & -0.101 & 0.133 & 0.081 & -0.074 & 0.116 \\
\hline & Specific items & 0.013 & -0.002 & 0.051 & 0.046 & 0.052 & 0.187 \\
\hline & Difference & 0.075 & -0.099 & 0.082 & 0.035 & -0.126 & -0.071 \\
\hline \multirow[t]{3}{*}{ Descriptor 3} & General items & 0.031 & 0.067 & 0.089 & 0.071 & 0.032 & 0.084 \\
\hline & Specific items & 0.120 & 0.092 & 0.156 & 0.051 & 0.055 & -0.048 \\
\hline & Difference & -0.089 & -0.025 & -0.067 & 0.02 & -0.023 & 0.132 \\
\hline \multirow[t]{3}{*}{ Descriptor 4} & General items & 0.061 & 0.022 & 0.014 & 0.044 & 0.017 & -0.026 \\
\hline & Specific items & 0.102 & 0.000 & -0.035 & 0.053 & 0.068 & -0.031 \\
\hline & Difference & -0.041 & 0.022 & 0.049 & -0.009 & -0.051 & 0.005 \\
\hline \multirow[t]{3}{*}{ Descriptor 5} & General items & -0.050 & 0.014 & -0.120 & 0.018 & 0.077 & -0.001 \\
\hline & Specific items & -0.174 & -0.076 & -0.092 & 0.045 & 0.053 & -0.043 \\
\hline & Difference & 0.124 & 0.09 & -0.028 & -0.027 & 0.024 & 0.042 \\
\hline \multicolumn{8}{|l|}{ Adjusted } \\
\hline \multirow[t]{3}{*}{ R-squared: } & General items & 0.082 & 0.104 & 0.123 & 0.118 & 0.084 & 0.063 \\
\hline & Specific items & 0.121 & 0.103 & 0.099 & 0.138 & 0.082 & 0.097 \\
\hline & Difference & -0.039 & 0.001 & 0.024 & -0.02 & 0.002 & -0.034 \\
\hline
\end{tabular}

There is little reason to go into detail on the results of the regression analyses. The differences between general and specific items appear to be quite arbitrary, and are seen as often when using list 3 as when using lists 1 and 2. Using specific anchors does not appear to improve the predictive validity of items. The same can be said 
of the results presented in Table 30, showing the regression coefficients of required level on hourly wage and job satisfaction. Also included in these analyses were mean shortages and surpluses for each descriptor, full results available on request from the authors.

Table 30

Explained variance (adjusted R Between-program variance for an item in absolute terms and as percentage of total item variance, mean of general versus specific items

\begin{tabular}{|c|c|c|c|c|c|c|c|}
\hline & & \multicolumn{4}{|c|}{ Hourly wage } & \multicolumn{2}{|c|}{ Job satisfaction } \\
\hline & & Dublin 1 & Dublin 2 & Dublin 3 & Dublin 1 & Dublin 2 & Dublin 3 \\
\hline \multirow[t]{3}{*}{ Descriptor 1} & General items & 0.025 & -0.007 & 0.223 & -0.161 & -0.041 & 0.083 \\
\hline & Specific items & 0.023 & 0.001 & -0.003 & 0.159 & 0.082 & 0.197 \\
\hline & Difference & 0.002 & -0.008 & 0.226 & -0.32 & -0.123 & -0.114 \\
\hline \multirow[t]{3}{*}{ Descriptor 2} & General items & 0.099 & -0.051 & -0.081 & 0.101 & 0.283 & 0.096 \\
\hline & Specific items & 0.037 & -0.013 & 0.216 & -0.023 & 0.196 & -0.063 \\
\hline & Difference & 0.062 & -0.038 & -0.297 & 0.124 & 0.087 & 0.159 \\
\hline \multirow[t]{3}{*}{ Descriptor 3} & General items & 0.236 & 0.170 & 0.252 & 0.013 & -0.092 & 0.038 \\
\hline & Specific items & 0.271 & 0.188 & 0.139 & 0.054 & -0.177 & 0.122 \\
\hline & Difference & -0.035 & -0.018 & 0.113 & -0.041 & 0.085 & -0.084 \\
\hline \multirow[t]{3}{*}{ Descriptor 4} & General items & -0.082 & 0.065 & 0.038 & 0.080 & 0.055 & 0.018 \\
\hline & Specific items & -0.200 & -0.077 & 0.002 & -0.101 & 0.130 & 0.043 \\
\hline & Difference & 0.118 & 0.142 & 0.036 & 0.181 & -0.075 & -0.025 \\
\hline \multirow[t]{3}{*}{ Descriptor 5} & General items & -0.032 & 0.016 & -0.168 & 0.040 & 0.012 & 0.072 \\
\hline & Specific items & 0.099 & 0.186 & -0.050 & 0.003 & 0.009 & -0.063 \\
\hline & Difference & -0.131 & -0.17 & -0.118 & 0.037 & 0.003 & 0.135 \\
\hline \multicolumn{8}{|l|}{ Adjusted R- } \\
\hline \multirow[t]{3}{*}{ squared: } & General items & 0.331 & 0.370 & 0.284 & 0.090 & 0.115 & 0.079 \\
\hline & Specific items & 0.274 & 0.303 & 0.293 & 0.052 & 0.111 & 0.081 \\
\hline & Difference & 0.057 & 0.067 & -0.009 & 0.038 & 0.004 & -0.002 \\
\hline
\end{tabular}




\section{Conclusions}

\begin{tabular}{|c|c|}
\hline Hypotheses & Findings \\
\hline \multicolumn{2}{|l|}{1 Anchors versus no anchors } \\
\hline \multicolumn{2}{|l|}{1.1 Item non-response } \\
\hline $\begin{array}{l}\text { Item non-response (null) hypothesis 1: Scales using } \\
\text { clearly defined anchors representing the } \\
\text { hypothetical range of competences in the } \\
\text { population do not lead to more item non-response } \\
\text { than scales without anchors. }\end{array}$ & $\begin{array}{l}\text { Hypothesis is confirmed. Despite the fact that lists } \\
\text { using anchors in the competence questions put a } \\
\text { heavier claim on respondents, lists using anchors do } \\
\text { not automatically lead to higher item non-response } \\
\text { than lists without anchors. Although the best list in } \\
\text { this respect is Dublin list } 3 \text { (in which no anchors were } \\
\text { used), this list was not closely followed by the } \\
\text { regular list (also containing no anchors), but by list } 4 \text {, } \\
\text { containing the original O*NET anchors. }\end{array}$ \\
\hline \multicolumn{2}{|c|}{ Conclusion: the use of anchors does not lead to a higher item non-response. } \\
\hline \multicolumn{2}{|l|}{ 1.2 Distribution } \\
\hline $\begin{array}{l}\text { Overestimation hypothesis 1: Scales using clearly } \\
\text { defined anchors representing the hypothetical range } \\
\text { of competences in the population will be less } \\
\text { susceptible to overestimation than scales without } \\
\text { anchors. }\end{array}$ & $\begin{array}{l}\text { Hypothesis is confirmed. A comparison between lists } \\
1 \text { and } 2 \text { on one hand with list } 3 \text { on the other hand, } \\
\text { reveals that the use of anchors does reduce the } \\
\text { mean level considerably. }\end{array}$ \\
\hline $\begin{array}{l}\text { Distribution hypothesis } 1: \text { Scales using anchors } \\
\text { representing the hypothetical range of competences } \\
\text { in the population will more closely approximate a } \\
\text { normal distribution than scales without anchors. }\end{array}$ & $\begin{array}{l}\text { - Looking at the standard deviation, we found at best } \\
\text { only rather weak support for this hypothesis: there is } \\
\text { a moderate increase in the standard deviation of } \\
\text { own level, but only a rather slight increase for } \\
\text { required level. } \\
\text { - However, looking at the kurtosis we found } \\
\text { confirmation of this hypothesis: the own and } \\
\text { required levels according to list } 3 \text { are clearly more } \\
\text { peaked than those for lists } 1 \text { and } 2 \text {. } \\
\text { - Also consistent with the prediction of this } \\
\text { hypothesis, we found that skewness to the left is } \\
\text { more pronounced for own and required level for list } \\
3 \text { than for lists } 1 \text { and } 2 \text {. }\end{array}$ \\
\hline $\begin{array}{l}\text { Distribution hypothesis 2: Scales using anchors } \\
\text { representing the hypothetical range of competences } \\
\text { in the population will be more likely to elicit answers } \\
\text { across the full range than scales without anchors. }\end{array}$ & $\begin{array}{l}\text { Hypothesis is rejected: the lowest possible value is } \\
\text { strongly represented in all Dublin Lists for required } \\
\text { and particularly own level. }\end{array}$ \\
\hline $\begin{array}{l}\text { Distribution hypothesis 3: Scales using anchors } \\
\text { representing the hypothetical range of competences } \\
\text { in the population will be less susceptible to left or } \\
\text { right censuring than scales without anchors. }\end{array}$ & $\begin{array}{l}\text { The results offer some support for this hypothesis: } \\
\text { the answers to own and required competences are } \\
\text { slightly more concentrated in the highest possible } \\
\text { value for list } 3 \text { than for lists } 1 \text { and } 2 \text {. }\end{array}$ \\
\hline
\end{tabular}




\begin{tabular}{|c|c|}
\hline \multicolumn{2}{|l|}{ 1.3 Differentiation } \\
\hline $\begin{array}{l}\text { Differentiation hypothesis } 1 \text { (weak version): Scales } \\
\text { using anchors representing the hypothetical range } \\
\text { of competences in the population will differentiate } \\
\text { more on own level between bachelors and masters } \\
\text { graduates than scales without anchors. }\end{array}$ & $\begin{array}{l}\text { Hypothesis is rejected: there is disappointingly little } \\
\text { difference between HBO and WO for own and } \\
\text { required levels. }\end{array}$ \\
\hline $\begin{array}{l}\text { Differentiation hypothesis } 1 \text { (strong version): Scales } \\
\text { using anchors representing the hypothetical range } \\
\text { of competences in the population will yield a mean } \\
\text { own level of close to } 5 \text { for bachelors and close to } 7 \\
\text { for masters; scales without anchors will yield no } \\
\text { consistent mean level for bachelors or masters. }\end{array}$ & $\begin{array}{l}\text { Hypothesis is rejected: there is disappointingly little } \\
\text { difference between HBO and WO for own and } \\
\text { required levels. }\end{array}$ \\
\hline $\begin{array}{l}\text { Differentiation hypothesis 2: Scales using anchors } \\
\text { representing the hypothetical range of competences } \\
\text { in the population will differentiate more on own } \\
\text { level between study programs than scales without } \\
\text { anchors. }\end{array}$ & $\begin{array}{l}\text { Hypothesis is confirmed: scales using anchors } \\
\text { differentiate more on own level between study } \\
\text { programs than scales without anchors. }\end{array}$ \\
\hline $\begin{array}{l}\text { Differentiation hypothesis } 3 \text { (weak version): Scales } \\
\text { using anchors representing the hypothetical range } \\
\text { of competences in the population will differentiate } \\
\text { more on required level between graduates holding } \\
\text { jobs that require bachelors level and those holding } \\
\text { jobs requiring masters level qualifications than } \\
\text { scales without anchors. }\end{array}$ & $\begin{array}{l}\text { Hypothesis is confirmed: there is more difference } \\
\text { between the required level of those working at } \\
\text { compared to below their own level for lists } 1 \text { and } 2 \\
\text { (and list } 4 \text { as well) than for list } 3 \text { and the regular list. }\end{array}$ \\
\hline $\begin{array}{l}\text { Differentiation hypothesis } 3 \text { (strong version): Scales } \\
\text { using anchors representing the hypothetical range } \\
\text { of competences in the population will yield a } \\
\text { required own level of close to } 5 \text { for graduates } \\
\text { holding bachelors-level jobs and close to } 7 \text { for } \\
\text { graduates holding masters-level jobs; scales without } \\
\text { anchors will yield no consistent mean required level } \\
\text { for bachelors or masters level jobs. }\end{array}$ & $\begin{array}{l}\text { Hypothesis is rejected: the differences fall far short of } \\
\text { the } 2 \text { or (in the case of HBO graduates working at } \\
\text { junior college level) } 3 \text { scale points difference } \\
\text { between bachelors-level jobs and masters-level jobs. }\end{array}$ \\
\hline $\begin{array}{l}\text { Differentiation hypothesis } 4 \text { : Scales using anchors } \\
\text { representing the hypothetical range of competences } \\
\text { in the population will differentiate more on required } \\
\text { level between occupations than scales without } \\
\text { anchors. }\end{array}$ & $\begin{array}{l}\text { Hypothesis is not confirmed: all the Dublin lists show } \\
\text { more variance between occupational levels and } \\
\text { groups than the regular list: Lists } 1 \text { and } 2 \text { show the } \\
\text { greatest variance between occupational levels, and } \\
\text { lists } 3 \text { and } 4 \text { the greatest variance between } \\
\text { occupational groups. }\end{array}$ \\
\hline \multicolumn{2}{|c|}{$\begin{array}{l}\text { Conclusion: anchors do not differentiate better between } \mathrm{HBO} \text { and WO and between occupations. They do } \\
\text { however differentiate better between study programs and slightly better between occupational levels. }\end{array}$} \\
\hline \multicolumn{2}{|l|}{ 1.4 Prediction } \\
\hline $\begin{array}{l}\text { Prediction hypothesis 1: Scales using clearly defined } \\
\text { anchors representing the hypothetical range of } \\
\text { competences in the population to measure own }\end{array}$ & $\begin{array}{l}\text { Hypothesis is confirmed: list } 1 \text { performs best on the } \\
\text { graduates' general evaluation of the study program. }\end{array}$ \\
\hline
\end{tabular}




\begin{tabular}{|c|c|}
\hline $\begin{array}{l}\text { competences will be better predictors of graduates' } \\
\text { general evaluation of the study program than scales } \\
\text { without anchors. }\end{array}$ & \\
\hline $\begin{array}{l}\text { Prediction hypothesis 2: Scales using clearly defined } \\
\text { anchors representing the hypothetical range of } \\
\text { competences in the population to measure own and } \\
\text { required competences will be better predictors of } \\
\text { graduates' labour market outcomes than scales } \\
\text { without anchors. }\end{array}$ & $\begin{array}{l}\text { Weak confirmation for hypothesis: } \\
\text { a) gross hourly wage: } \\
\text { - based on required level, list } 1 \text { performs best } \\
\text { - based on importance, list } 3 \text { performs best } \\
\text { b) job satisfaction: } \\
\text { - based on required level, regular list performs best } \\
\text { - based on importance, list } 4 \text { explains slightly more } \\
\text { variance than lists } 2 \text { and 3, and substantially more } \\
\text { than list } 1\end{array}$ \\
\hline \multicolumn{2}{|c|}{$\begin{array}{l}\text { Conclusion: anchors (list 1) predict graduates' evaluation of study program and gross hourly wage better, } \\
\text { but regular list predicts job satisfaction better. }\end{array}$} \\
\hline \multicolumn{2}{|l|}{2 O*NET anchors versus adapted anchors } \\
\hline $\begin{array}{l}\text { Distribution hypothesis 4: Scales using anchors } \\
\text { adapted to the Dublin descriptors will show better } \\
\text { distributional characteristics than scales using the } \\
\text { original O*NET anchors. }\end{array}$ & $\begin{array}{l}\text { Hypothesis confirmed, looking at the larger } \\
\text { overestimation (higher means, especially with } \\
\text { respect to required level) and the smaller spread in } \\
\text { answers (standard deviation) in the } \mathrm{O}^{*} \mathrm{NET} \text { list. }\end{array}$ \\
\hline $\begin{array}{l}\text { Differentiation hypothesis 5: Scales using anchors } \\
\text { adapted to the Dublin descriptors will differentiate } \\
\text { more between educational and occupational levels } \\
\text { and fields than scales using the original O*NET } \\
\text { anchors. }\end{array}$ & $\begin{array}{l}\text { - Not confirmed (HBO-WO; occupational groups; jobs } \\
\text { below/on own educational level) } \\
\text { - Confirmed (study programs; occupational levels) }\end{array}$ \\
\hline $\begin{array}{l}\text { Prediction hypothesis 3: Scales using anchors adapted } \\
\text { to the Dublin descriptors to measure own and } \\
\text { required competences will be better predictors of } \\
\text { educational and labour market outcomes than scales } \\
\text { using the original O*NET anchors. }\end{array}$ & $\begin{array}{l}\text { - Hypothesis not confirmed for educational } \\
\text { outcomes: despite the finding that list } 1 \text { (adapted } \\
\text { anchors) predicts best, list } 2 \text { (also adapted anchors) } \\
\text { doesn't predict better than list } 4 \text {. } \\
\text { - Hypothesis not confirmed for job satisfaction: list } 2 \\
\text { predicts best and list } 4 \text { worst. } \\
\text { - Hypothesis confirmed for wage: list } 1 \text { and } 2 \text { better } \\
\text { predictors than list } 4 \text {. }\end{array}$ \\
\hline $\begin{array}{l}\text { Item non-response hypothesis } 2 \text { : Scales using anchors } \\
\text { adapted to the Dublin descriptors lead to less item } \\
\text { non-response than scales using the original O*NET } \\
\text { anchors. }\end{array}$ & $\begin{array}{l}\text { Hypothesis not confirmed: list } 4 \text { lower non-response } \\
\text { than list } 1 \text { and } 2 \text {. }\end{array}$ \\
\hline \multicolumn{2}{|c|}{ Conclusion: The $0 *$ NET anchors and the adapted anchors do not differ much. } \\
\hline \multicolumn{2}{|l|}{3 Importance versus required level } \\
\hline $\begin{array}{l}\text { Distribution hypothesis 5: Required level based on } \\
\text { anchors representing the hypothetical range of } \\
\text { competences in the population will show better } \\
\text { distributional characteristics than importance based } \\
\text { on scales without anchors. }\end{array}$ & Hypothesis not confirmed. \\
\hline
\end{tabular}




\begin{tabular}{|c|c|}
\hline $\begin{array}{l}\text { Differentiation hypothesis 6: Required level based on } \\
\text { anchors representing the hypothetical range of } \\
\text { competences in the population will differentiate } \\
\text { more between educational and occupational levels } \\
\text { and fields than importance based on scales without } \\
\text { anchors. }\end{array}$ & $\begin{array}{l}\text { - Hypothesis not confirmed for educational level and } \\
\text { study program. } \\
\text { - Hypothesis confirmed for occupational } \\
\text { levels/groups and education-job level match. }\end{array}$ \\
\hline $\begin{array}{l}\text { Prediction hypothesis } 4 \text { : Required level based on } \\
\text { anchors representing the hypothetical range of } \\
\text { competences in the population to measure own } \\
\text { competences will be better predictors of labour } \\
\text { market outcomes than importance based on scales } \\
\text { without anchors. }\end{array}$ & $\begin{array}{l}\text { Hypothesis confirmed in the analysis of the wage, } \\
\text { but not in the analysis of job satisfaction. }\end{array}$ \\
\hline $\begin{array}{l}\text { Item non-response (null) hypothesis 3: Required level } \\
\text { based on anchors representing the hypothetical } \\
\text { range of competences in the population does not } \\
\text { lead to more item non-response than importance } \\
\text { based on scales without anchors. }\end{array}$ & $\mathrm{Hyp}$ \\
\hline $\begin{array}{l}\text { Discrepancy hypothesis 1: Discrepancies (shortages } \\
\text { and surpluses) between own and required level } \\
\text { based on anchors representing the hypothetical } \\
\text { range of competences in the population are better } \\
\text { indicators of overall shortages and surpluses than } \\
\text { discrepancies between (standardized) importance } \\
\text { and (standardized) own level. }\end{array}$ & $\begin{array}{l}\text { Hypothesis confirmed, although the differences are } \\
\text { quite modest }\end{array}$ \\
\hline \multicolumn{2}{|c|}{$\begin{array}{l}\text { Conclusion: the questions on required level perform only slightly better than the questions on } \\
\text { importance. }\end{array}$} \\
\hline \multicolumn{2}{|l|}{4 General versus specific items } \\
\hline $\begin{array}{l}\text { Overestimation hypothesis 2: Items with situation- } \\
\text { specific anchors for own and required level will be } \\
\text { less susceptible to overestimation than items with } \\
\text { generalized anchors. }\end{array}$ & $\begin{array}{l}\text { Hypothesis confirmed: mean scores are somewhat } \\
\text { lower for general items than for specific items, } \\
\text { especially on required level. The difference seems to } \\
\text { be partly due to substantive differences between } \\
\text { items, but part of the difference is attributable to the } \\
\text { anchors used. }\end{array}$ \\
\hline $\begin{array}{l}\text { Distribution hypothesis 4: Items with situation-specific } \\
\text { anchors for own and required level will show better } \\
\text { distributional characteristics than items with } \\
\text { generalized anchors. }\end{array}$ & $\begin{array}{l}\text { Hypothesis partially confirmed: there is no effect of } \\
\text { specific anchors on the standard deviation, but the } \\
\text { distributions are slightly less peaked and less skewed } \\
\text { than similar items using general anchors. }\end{array}$ \\
\hline $\begin{array}{l}\text { Differentiation hypothesis 5: Items with situation- } \\
\text { specific anchors for own and required level will } \\
\text { differentiate more between educational and } \\
\text { occupational levels and fields than items with } \\
\text { generalized anchors. }\end{array}$ & $\begin{array}{l}\text { Hypothesis not confirmed: specific items do not } \\
\text { differentiate any better between university and HBO } \\
\text { graduates than general items. Although specific } \\
\text { items show greater variance between programs and } \\
\text { occupations than general items, this appears to be } \\
\text { due to the differences in substance between the } \\
\text { items rather than to the anchors. }\end{array}$ \\
\hline 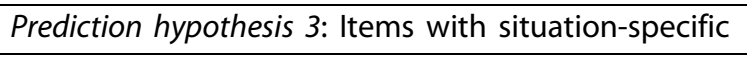 & s \\
\hline
\end{tabular}




\begin{tabular}{|c|c|}
\hline $\begin{array}{l}\text { anchors for own and required level will be better } \\
\text { predictors of educational and labour market } \\
\text { outcomes than items with generalized anchors. }\end{array}$ & $\begin{array}{l}\text { perform better or worse than general items as } \\
\text { predictors of labour market outcomes. }\end{array}$ \\
\hline \multicolumn{2}{|c|}{$\begin{array}{l}\text { Conclusion: Items containing specific anchors are less susceptible to self-overestimation and show } \\
\text { somewhat better distributional characteristics than items containing general anchors, but do not } \\
\text { differentiate better between programs and occupations, and do not predict outcomes better. }\end{array}$} \\
\hline \multicolumn{2}{|l|}{5 Question order } \\
\hline $\begin{array}{l}\text { Distribution (null) hypothesis 6: It makes no difference } \\
\text { for the distribution of answers whether the question } \\
\text { on own level or the question on importance is asked } \\
\text { first. }\end{array}$ & $\begin{array}{l}\text { Hypothesis confirmed: list } 1 \text { hardly differs from list } 2 \text {, } \\
\text { looking at the mean, standard deviation, kurtosis } \\
\text { (except for attention wanted) and skewness. }\end{array}$ \\
\hline $\begin{array}{l}\text { Differentiation (null) hypothesis 7: It makes no } \\
\text { difference for the differentiation between } \\
\text { educational and occupational levels and fields } \\
\text { whether the question on own level or the question } \\
\text { on importance is asked first. }\end{array}$ & $\begin{array}{l}\text { Hypothesis confirmed: in general the differences } \\
\text { between list } 1 \text { and list } 2 \text { in this respect are quite } \\
\text { small. }\end{array}$ \\
\hline $\begin{array}{l}\text { Prediction (null) hypothesis 5: It makes no difference } \\
\text { for the prediction of graduates' general evaluation of } \\
\text { the study program or labour market outcomes } \\
\text { whether the question on own level or the question } \\
\text { on importance is asked first. }\end{array}$ & $\begin{array}{l}\text { Hypothesis not confirmed: in terms of explained } \\
\text { variance, list } 1 \text { performs better than list } 2 \text {. }\end{array}$ \\
\hline $\begin{array}{l}\text { Item non-response (null) hypothesis 4: It makes no } \\
\text { difference for item non-response whether the } \\
\text { question on own level or the question on } \\
\text { importance is asked first. }\end{array}$ & $\begin{array}{l}\text { Hypothesis not confirmed: list } 1 \text { shows a higher item } \\
\text { non-response per competence item (own level) than } \\
\text { list } 2 \text {. }\end{array}$ \\
\hline & \\
\hline
\end{tabular}

\section{Recommendation}

The above-mentioned results clearly show that using anchors in phrasing the questions offers no more than a weak ray of hope of improvement. The degree of improvement however is too meagre to justify an investment in the further development of an instrument with anchors. This recommendation is particularly based on the finding that phrasing the questions using anchors does differentiate not better between $\mathrm{HBO}$ and $\mathrm{WO}$ than the phrasing of the questions without anchors. 


\section{Appendix 1: Operationalisatie Dublin descriptoren}

Omschrijving Dublin descriptor 'Kennis en inzicht'

\begin{tabular}{|l|l|}
\hline & \multicolumn{1}{|c|}{ Kennis en inzicht } \\
\hline $\begin{array}{l}\text { Kwalificaties } \\
\text { MBO }\end{array}$ & $\begin{array}{l}\text { Heeft aantoonbare kennis en inzicht van een vakgebied, waarbij wordt voortgebouwd op } \\
\text { het niveau bereikt in het voortgezet onderwijs. Functioneert doorgaans op een niveau } \\
\text { waarbij het bijhouden van de nieuwste ontwikkelingen niet vereist is. }\end{array}$ \\
\hline $\begin{array}{l}\text { Kwalificaties } \\
\text { Bachelors }\end{array}$ & $\begin{array}{l}\text { Heeft aantoonbare kennis en inzicht van een vakgebied, waarbij wordt voortgebouwd op } \\
\text { het niveau bereikt in het voortgezet onderwijs en dit wordt overtroffen; functioneert } \\
\text { doorgaans op een niveau waarop met ondersteuning van gespecialiseerde handboeken, } \\
\text { enige aspecten voorkomen waarvoor kennis van de laatste ontwikkelingen in het vakgebied } \\
\text { vereist is. }\end{array}$ \\
\hline $\begin{array}{l}\text { Kwalificaties } \\
\text { Masters }\end{array}$ & $\begin{array}{l}\text { Heeft aantoonbare kennis en inzicht, gebaseerd op de kennis en het inzicht op het niveau } \\
\text { van Bachelor en die deze overtreffen en/of verdiepen, alsmede een basis of een kans bieden } \\
\text { om een originele bijdrage te leveren aan het ontwikkelen en/of toepassen van ideeën, vaak } \\
\text { in onderzoeksverband. }\end{array}$ \\
\hline
\end{tabular}

Operationalisatie Dublin descriptor 'Kennis en inzicht'

1. Vakkennis: Kennis en inzicht van het werkgebied van de opleiding

$\begin{array}{ll}\text { 01a Hoe belangrijk is vakkennis voor het } 1 \text { niet belangrijk } \\ \text { adequaat uitoefenen van uw functie? } & 2 \text { enigszins belangrijk } \\ 3 \text { belangrijk } \\ 4 \text { heel belangrijk } \\ 5 \text { extreem belangrijk }\end{array}$


01b Welk niveau van vakkennis is nodig om uw huidige functie goed uit te oefenen?

Dublin lists 1, 2 and 4:5 huidige functie

eigen niveau

1

01c Hoe schat u uw eigen niveau van vakkennis

$\leftarrow$ kennis van basisprincipes van het $\rightarrow$ in? werkgebied

Dublin list 3: huidige functie 1 matig

2

3

4

5

6

7

8 uitmuntend

eigen niveau 
02b Welk niveau van originaliteit is nodig om uw Dublin lists 1 and 2:

huidige functie goed uit te oefenen?

1

02c Hoe schat $u$ uw eigen niveau van originaliteit

$2 \leftarrow$ ontwerpen van nieuwe procedures in een $\rightarrow 2$

in? secretariaat om de werkefficiëntie te verbeteren

3

4

$5 \leftarrow$ ontwerp van een nieuwe maatregel om $\rightarrow \quad 5$

6 het ziekteverzuim in een bedrijf terug te dringen

$7 \longleftarrow$ ontwikkelen van een nieuwe methode om $\rightarrow 7$ patiënten sneller te laten revalideren

\section{Dublin list 3:}

huidige functie 1 matig

2

3

4

5

6

7

8 uitmuntend

eigen niveau

\section{Dublin list 4:} huidige functie

eigen niveau 1

$2 \leftarrow$ gebruiken van een creditcard om een $\rightarrow \quad 2$ gesloten deur te openen

3

$4 \leftarrow$ ontwerp van een nieuwe taakverdeling $\rightarrow \quad 4$ om het werk interessanter te maken voor werknemers

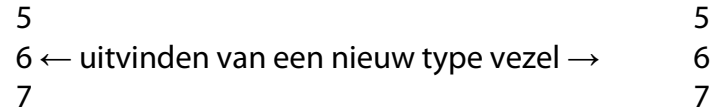

02d Moet in de opleiding meer of minder 1 veel meer aandacht aandacht besteed worden aan de 2 meer aandacht ontwikkeling van originaliteit?

3 niet meer en niet minder

4 minder aandacht

5 veel minder aandacht 


\section{Het up-to-date houden van vakkennis: Eigen kennispeil up-to-date houden}

03a Hoe belangrijk is het up-to-date houden van 1 niet belangrijk vakkennis voor het adequaat uitoefenen van 2 enigszins belangrijk uw functie?

3 belangrijk

4 heel belangrijk

5 extreem belangrijk

03b Welk niveau van up-to-date houden van Dublin lists 1 and 2: vakkennis is nodig om uw huidige functie huidige functie goed uit te oefenen?

1

$2 \leftarrow$ op de hoogte blijven van $\rightarrow$

eigen niveau onderhoudsprocedures voor de meest

03c Hoe schat u uw eigen niveau van up-to-date voorkomende reparatie van auto's houden van vakkennis in?

Dublin list 3:

huidige functie

eigen niveau

1 matig

2

3

4

5

6

7

8 uitmuntend

Dublin list 4:

$\begin{array}{lr}\text { huidige functie } & \text { eigen niveau } \\ 1 & 1 \\ 2 \leftarrow \text { bijhouden van prijsveranderingen in een } \rightarrow & 2 \\ & \text { kleine winkel } \\ 3 & \end{array}$


03d Moet in de opleiding meer of minder 1 veel meer aandacht aandacht besteed worden aan de 2 meer aandacht ontwikkeling van het vermogen om 3 niet meer en niet minder vakkennis up-to-date te houden?

4 minder aandacht

5 veel minder aandacht

Omschrijving Dublin descriptor 'Toepassen kennis en inzicht'

\begin{tabular}{|l|l|}
\hline $\begin{array}{l}\text { Kwalificaties } \\
\text { MBO }\end{array}$ & $\begin{array}{l}\text { Is in staat zijn/haar kennis en inzicht op dusdanige wijze toe te passen, dat dit een } \\
\text { professionele benadering van zijn/haar werk laat zien, en beschikt bovendien over } \\
\text { competenties die voor een correcte uitvoering van het vak zorgen. }\end{array}$ \\
\hline $\begin{array}{l}\text { Kwalificaties } \\
\text { Bachelors }\end{array}$ & $\begin{array}{l}\text { Is in staat om zijn/haar kennis en inzicht op dusdanige wijze toe te passen, dat dit een } \\
\text { professionele benadering van zijn/haar werk of beroep laat zien, en beschikt verder over } \\
\text { competenties voor het opstellen en verdiepen van argumentaties en voor het oplossen van } \\
\text { problemen op het vakgebied. } \\
\text { Masters }\end{array}$ \\
$\begin{array}{l}\text { Is in staat om kennis en inzicht en probleemoplossende vermogens toe te passen in nieuwe } \\
\text { of onbekende omstandigheden binnen een bredere (of multidisciplinaire) context die } \\
\text { gerelateerd is aan het vakgebied; is in staat om kennis te integreren en met complexe } \\
\text { materie om te gaan. }\end{array}$ \\
\hline
\end{tabular}

\section{Operationalisatie Dublin descriptor 'Toepassen kennis en inzicht'}

\section{Toepassen van kennis en inzicht: Het vermogen om kennis en inzicht toe te passen}

04a Hoe belangrijk is het toepassen van kennis 1 niet belangrijk

voor het adequaat uitoefenen van uw 2 enigszins belangrijk

functie?

3 belangrijk

4 heel belangrijk

5 extreem belangrijk 
04b Welk niveau van toepassen van kennis en Dublin lists 1, 2 and 4:

inzicht is nodig om uw huidige functie goed huidige functie

eigen niveau

uit te oefenen?

1

$2 \leftarrow$ standaardproblemen op het werkgebied $\rightarrow 2$

herkennen en oplossen

04c Hoe schat u uw eigen niveau van toepassen

Dublin list 3:

huidige functie

1 matig

eigen niveau

2

3

4

5

6

7

8 uitmuntend

04d Moet in de opleiding meer of minder 1 veel meer aandacht aandacht besteed worden aan de 2 meer aandacht ontwikkeling van het vermogen om kennis en 3 niet meer en niet minder inzicht toe te passen?

4 minder aandacht

5 veel minder aandacht

\section{Probleem-oplossend vermogen: Analyseren van problemen en het evalueren} van relevante informatie om oplossingen te ontwikkelen en te implementeren

05a Hoe belangrijk is het probleemoplossend 1 niet belangrijk

vermogen voor het adequaat uitoefenen van 2 enigszins belangrijk

uw functie?

3 belangrijk

4 heel belangrijk

5 extreem belangrijk 
05b Welk niveau van probleemoplossend Dublin lists 1 and 2: vermogen is nodig om uw huidige functie huidige functie

eigen niveau goed uit te oefenen?

1

$2 \leftarrow$ standaardreparatie van een defect $\rightarrow \quad 2$ voertuig

05c Hoe schat $u$ uw eigen niveau van $3 \quad 3$ probleemoplossend vermogen in?

4

$5 \leftarrow$ ontwikkelen en implementeren van een $\rightarrow \quad 5$ rampenplan voor een middelgroot bedrijf

6

$7 \leftarrow$ ontwerp van nieuwe verbindingen in een $\rightarrow 7$ bouwconstructie om te besparen op materialen

\section{Dublin list 3:}

$\begin{array}{lr}\text { huidige functie } & \text { eigen niveau } \\ 1 \text { matig } & 1 \\ 2 & 2 \\ 3 & 3 \\ 4 & 4 \\ 5 & 5 \\ 6 & 6 \\ 7 & 7 \\ 8 \text { uitmuntend } & 8\end{array}$

\section{Dublin list 4:}

huidige functie eigen niveau 1

$2 \leftarrow$ bij elkaar zieken van gereedschap om een $\rightarrow 2$ taak uit te voeren

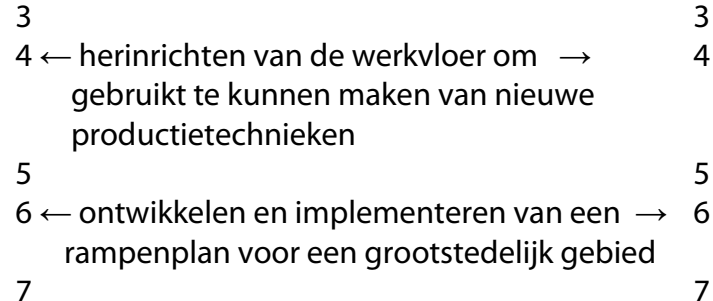

05d Moet in de opleiding meer of minder 1 veel meer aandacht aandacht besteed worden aan de 2 meer aandacht ontwikkeling van probleemoplossend 3 niet meer en niet minder vermogen?

4 minder aandacht

5 veel minder aandacht 


\title{
6. Analyseren van gegevens en informatie: Het vermogen om betekenisvolle informatie te destilleren uit een grote hoeveelheid gegevens
}

\author{
06a Hoe belangrijk is het analyseren van 1 niet belangrijk \\ gegevens voor het adequaat uitoefenen van 2 enigszins belangrijk \\ uw functie? \\ 3 belangrijk \\ 4 heel belangrijk \\ 5 extreem belangrijk
}

06b Welk niveau van analyseren van gegevens is nodig om uw huidige functie goed uit te oefenen?

Dublin lists 1 and 2: huidige functie eigen niveau

1

06c Hoe schat $u$ uw eigen niveau van analyseren

$2 \leftarrow$ maken van tabellen of grafieken over de $\rightarrow \quad 2$ bedrijfsresultaten

van gegevens in?

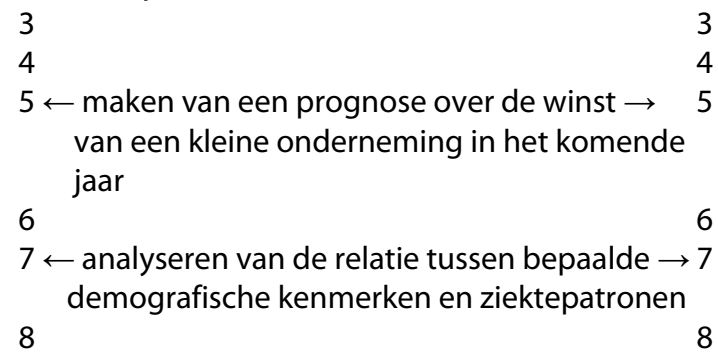

Dublin list 3:

huidige functie

eigen niveau

1 matig

2

3

4

5

6

7

8 uitmuntend

\section{Dublin list 4:} huidige functie

1

$2 \leftarrow$ opsporen va bestelling

3

$4 \leftarrow$ bepalen van de rentekosten om een $\rightarrow$ nieuw gebouw te financieren

$6 \leftarrow$ analyseren van de kosten van medische $\rightarrow \quad 6$ zorg voor alle ziekenhuizen in het land 
06d Moet in de opleiding meer of minder 1 veel meer aandacht aandacht besteed worden aan het 2 meer aandacht ontwikkelen van analyse van gegevens? $\quad 3$ niet meer en niet minder

4 minder aandacht

5 veel minder aandacht

Omschrijving Dublin descriptor 'Oordeelsvorming'

\begin{tabular}{|c|c|}
\hline & Oordeelsvorming \\
\hline $\begin{array}{l}\text { Kwalificaties } \\
\text { MBO }\end{array}$ & $\begin{array}{l}\text { Is in staat om relevante gegevens te interpreteren en te gebruiken om een oordeel te } \\
\text { geven aan de hand van duidelijk gedefinieerde alsook abstracte vraagstukken. }\end{array}$ \\
\hline $\begin{array}{l}\text { Kwalificaties } \\
\text { Bachelors }\end{array}$ & $\begin{array}{l}\text { Is in staat om relevante gegevens te verzamelen en interpreteren (meestal op het } \\
\text { vakgebied) met het doel een oordeel te vormen dat mede gebaseerd is op het afwegen } \\
\text { van relevante sociaal- maatschappelijke, wetenschappelijke of ethische aspecten. }\end{array}$ \\
\hline $\begin{array}{l}\text { Kwalificaties } \\
\text { Masters }\end{array}$ & $\begin{array}{l}\text { Is in staat om oordelen te formuleren op grond van onvolledige of beperkte informatie en } \\
\text { daarbij rekening te houden met sociaal-maatschappelijke en ethische } \\
\text { verantwoordelijkheden, die zijn verbonden aan het toepassen van de eigen kennis en } \\
\text { oordelen. }\end{array}$ \\
\hline
\end{tabular}

\section{Operationalisatie Dublin descriptor 'Oordeelsvorming'}

\section{Oordeelsvorming: Verzamelen van relevante gegevens en interpreteren met het doel tot een oordeel te komen}

07a Hoe belangrijk is oordeelsvorming voor het 1 niet belangrijk adequaat uitoefenen van uw functie?

2 enigszins belangrijk

3 belangrijk

4 heel belangrijk

5 extreem belangrijk 
07b Welk niveau van oordeelsvorming is nodig om uw huidige functie goed uit te oefenen?

ublin lists 1, 2 and 4:

huidige functie

eigen niveau

1

07c Hoe schat $u$ uw eigen niveau van

$2 \leftarrow$ in standaard situaties tot een juiste $\rightarrow \quad 2$

oordeelsvorming in? oordeelsvorming komen

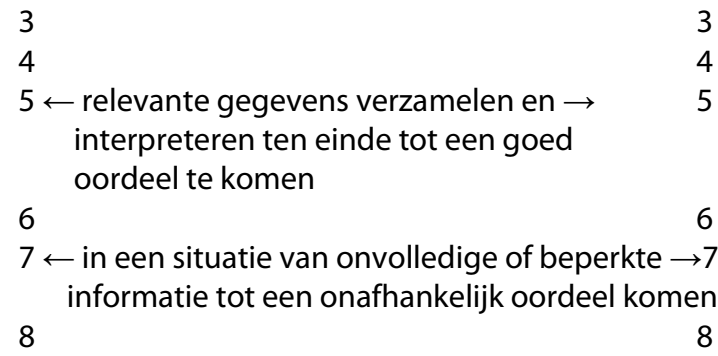

Dublin list 3:

huidige functie

eigen niveau

1 matig

2

3

4

5

6

7

8 uitmuntend

07d Moet in de opleiding meer of minder 1 veel meer aandacht aandacht besteed worden aan het 2 meer aandacht ontwikkelen van oordeelsvorming?

3 niet meer en niet minder

4 minder aandacht

5 veel minder aandacht

\section{Kritisch denkvermogen: Door logisch redeneren sterke en zwakke punten in een redenering of aanpak identificeren}

$\begin{array}{ll}\text { Hoe belangrijk is kritisch denkvermogen voor } & 1 \text { niet belangrijk } \\ \text { het adequaat uitoefenen van uw functie? } & 2 \text { enigszins belangrijk } \\ & 3 \text { belangrijk } \\ & 4 \text { heel belangrijk } \\ & 5 \text { extreem belangrijk }\end{array}$


08b Welk niveau van is kritisch denkvermogen is nodig om uw huidige functie goed uit te oefenen?

Dublin lists 1 and 2:

huidige functie

eigen niveau

1

$2 \leftarrow$ evalueren van klachten van klanten en het $\rightarrow 2$ nemen van adequate actie

08c Hoe schat $u$ uw eigen niveau van is kritisch denkvermogen in?

$\begin{array}{lrr}3 & & 3 \\ 4 & & 4 \\ 5 \leftarrow \text { evalueren van een conflict tussen een } \rightarrow & 5 \\ & \text { supervisor en een ondergeschikte en het } & \\ & \text { voorstellen van een oplossing } \\ 6 & & 6 \\ 7 \leftarrow \text { het schrijven van een verweerschrift } \rightarrow & 7 \\ 8 & 8\end{array}$

\section{Dublin list 3:}

huidige functie

eigen niveau

1 matig

2

3

4

5

6

7

8 uitmuntend

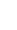
7

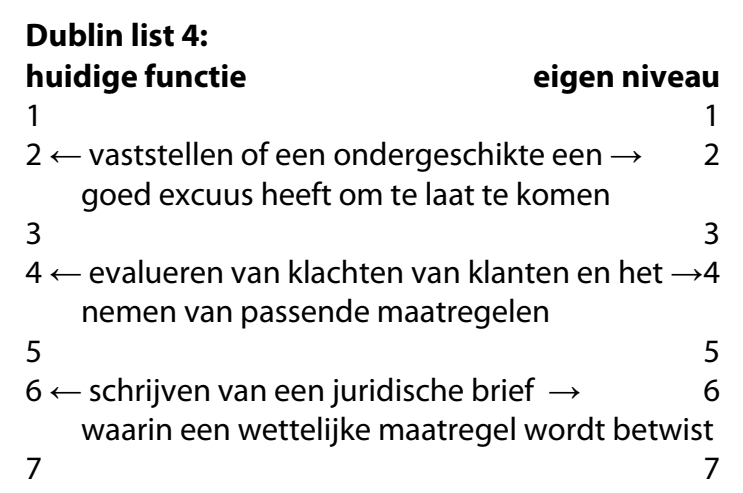

08d Moet in de opleiding meer of minder 1 veel meer aandacht aandacht besteed worden aan het 2 meer aandacht ontwikkelen van kritisch denkvermogen? $\quad 3$ niet meer en niet minder

4 minder aandacht

5 veel minder aandacht 
9. Besluitvormingsvaardigheden: Het vermogen om op basis van een analyse en evaluatie van informatie tot een beslissing te komen over de gewenste aanpak van een probleem

09a Hoe belangrijk zijn besluitvormingsvaardig- 1 niet belangrijk

heden voor het adequaat uitoefenen van uw 2 enigszins belangrijk

functie?

3 belangrijk

4 heel belangrijk

5 extreem belangrijk

09b Welk niveau van besluitvormingsvaardig- Dublin lists 1 and 2: heden is nodig om uw huidige functie goed huidige functie uit te oefenen?

eigen niveau

1

$2 \leftarrow$ vaststellen van de menukaart in een $\rightarrow \quad 2$

09c Hoe schat u uw eigen niveau van besluit- 3 restaurant

vormingsvaardigheden in?

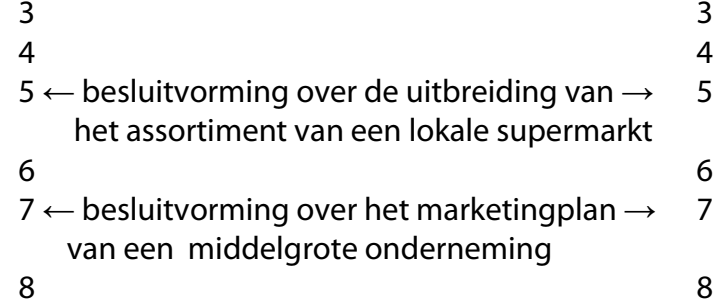

\section{Dublin list 3:}

huidige functie

eigen niveau

1 matig

2

3

4

5

6

7

8 uitmuntend

\section{Dublin list 4:} huidige functie

1

$2 \leftarrow$ vaststellen van het menu in een cafetaria $\rightarrow 2$

3

$4 \leftarrow$ kiezen van de locatie van een groot $\rightarrow \quad 4$ warenhuis

$\begin{array}{lrr}5 & 5 \\ 6 \leftarrow \text { finale beslissing nemen over een } \rightarrow & 6 \\ 7 & \text { 5-jarenplan van een onderneming } & 6 \\ 7 & 7\end{array}$ 
09d Moet in de opleiding meer of minder 1 veel meer aandacht aandacht besteed worden aan het 2 meer aandacht ontwikkelen van besluitvormingsvaardig- 3 niet meer en niet minder heden? 4 minder aandacht

5 veel minder aandacht

Omschrijving Dublin descriptor 'Communicatie'

\begin{tabular}{|l|l|}
\hline $\begin{array}{l}\text { Kwalificaties } \\
\text { MBO }\end{array}$ & $\begin{array}{l}\text { Communicatie } \\
\text { Is in staat om te communiceren over eigen inzichten, vaardigheden en activiteiten met } \\
\text { collega's, leidinggevenden, en klanten }\end{array}$ \\
\hline $\begin{array}{l}\text { Kwalificaties } \\
\text { Bachelors }\end{array}$ & $\begin{array}{l}\text { Is in staat om informatie, ideeën en oplossingen over te brengen op een publiek bestaande } \\
\text { uit specialisten of niet-specialisten. }\end{array}$ \\
\hline $\begin{array}{l}\text { Kwalificaties } \\
\text { Masters }\end{array}$ & $\begin{array}{l}\text { Is in staat om conclusies, alsmede de kennis, motieven en overwegingen die hieraan ten } \\
\text { grondslag liggen, duidelijk en ondubbelzinnig over te brengen op een publiek van } \\
\text { specialisten of niet-specialisten. }\end{array}$ \\
\hline
\end{tabular}

\section{Operationalisatie Dublin descriptor 'Communicatie'}

10. Communicatie: Het vermogen om informatie, ideeën en oplossingen aan een publiek van specialisten en niet-specialisten over te brengen

10a Hoe belangrijk is communicatie voor het 1 niet belangrijk adequaat uitoefenen van uw functie?

2 enigszins belangrijk

3 belangrijk

4 heel belangrijk

5 extreem belangrijk

10b Welk niveau van communicatie is nodig om Dublin lists 1, 2 and 4: uw huidige functie goed uit te oefenen? huidige functie 1

10c Hoe schat $u$ uw eigen niveau van communicatie in?

$2 \leftarrow$ informatie overbrengen $\rightarrow \quad 2$

3

4

$5 \leftarrow$ ideeën en oplossingen overbrengen $\rightarrow \quad 5$

$6 \quad 6$

$7 \leftarrow$ conclusies alsmede de kennis, $\rightarrow \quad 7$ motieven en overwegingen die hieraan ten grondslag liggen overtuigend overbrengen 


\section{Dublin list 3:}

$\begin{array}{lr}\text { huidige functie } & \text { eigen niveau } \\ 1 \text { matig } & 1 \\ 2 & 2 \\ 3 & 3 \\ 4 & 4 \\ 5 & 5 \\ 6 & 6 \\ 7 & 7 \\ 8 \text { uitmuntend } & 8\end{array}$

$10 \mathrm{~d}$ Moet in de opleiding meer of minder 1 veel meer aandacht aandacht besteed worden aan het 2 meer aandacht ontwikkelen van communicatievermogen? 3 niet meer en niet minder

4 minder aandacht

5 veel minder aandacht

11. Schriftelijke presentatie: Het vermogen om informatie schriftelijk te presenteren op een manier dat anderen het begrijpen

11a Hoe belangrijk is schriftelijke presentatie voor 1 niet belangrijk

het adequaat uitoefenen van uw functie? 2 enigszins belangrijk

3 belangrijk

4 heel belangrijk

5 extreem belangrijk

11b Welk niveau van schriftelijke presentatie is Dublin lists 1 and 2:

nodig om uw huidige functie goed uit te huidige functie

oefenen?

1

$2 \leftarrow$ maken van een verslag van het $\rightarrow \quad 2$ directieoverleg

11c Hoe schat u uw eigen niveau van schriftelijke presentatie in?

$\begin{array}{lr}3 & 3 \\ 4 & 4 \\ 5 \leftarrow \text { maken van een journalistieke bijdrage } \rightarrow & 5 \\ \quad \text { over de resultaten van een onderzoek } & \\ 6 & 6 \\ 7 \leftarrow \text { maken van een wetenschappelijk rapport } \rightarrow & 7 \\ \quad \text { over verricht onderzoek } & 8\end{array}$

Dublin list 3:

huidige functie

eigen niveau

1 matig

2

3

4

5

6

7

8 uitmuntend 


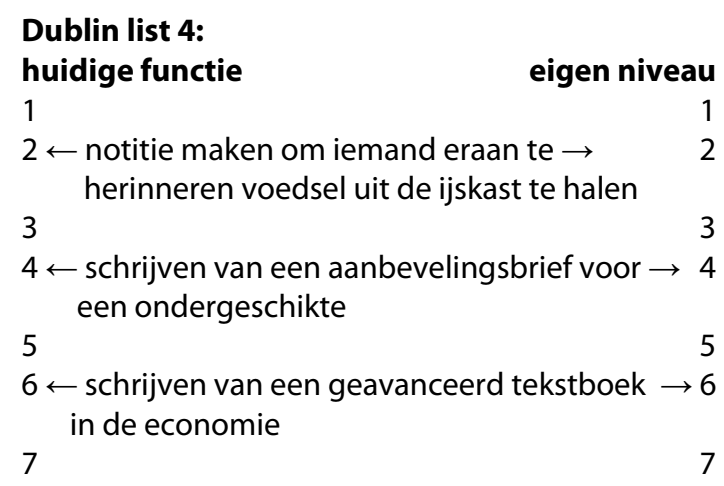

11d Moet in de opleiding meer of minder 1 veel meer aandacht aandacht besteed worden aan het 2 meer aandacht ontwikkelen van schriftelijke presentatie- 3 niet meer en niet minder vaardigheden?

4 minder aandacht

5 veel minder aandacht

12. Mondelinge presentatie: Het vermogen om informatie op een heldere wijze mondeling te communiceren

12a Hoe belangrijk is mondelinge presentatie 1 niet belangrijk voor het adequaat uitoefenen van uw 2 enigszins belangrijk functie?

3 belangrijk

4 heel belangrijk

5 extreem belangrijk

12b Welk niveau van mondelinge presentatie is Dublin lists 1 and 2: nodig om uw huidige functie goed uit te huidige functie eigen niveau oefenen?

$\begin{array}{ll}1 & \\ 2 \leftarrow \text { uitleg aan toeristen over de belangrijke } \rightarrow & 2 \\ & \text { attracties in de omgeving } \\ 3 & 3 \\ 4 & 4 \\ 5 \leftarrow \text { houden van een presentatie op een } \rightarrow & 5 \\ \quad \text { conferentie } & 6 \\ 6 \quad \text { houden van een slotpleidooi in een } \rightarrow & 7 \\ 7 \leftarrow \text { hochtzaak } & 8 \\ 8 \quad \text { r } & 6\end{array}$




\section{Dublin list 3:}

$\begin{array}{lr}\text { huidige functie } & \text { eigen niveau } \\ 1 \text { matig } & 1 \\ 2 & 2 \\ 3 & 3 \\ 4 & 4 \\ 5 & 5 \\ 6 & 6 \\ 7 & 7 \\ 8 \text { uitmuntend } & 8\end{array}$

\section{Dublin list 4:}

huidige functie eigen niveau

1

$2 \leftarrow$ begroeten van toeristen en uitleggen van $\rightarrow 2$ toeristische attracties

3

$4 \leftarrow$ interviewen van sollicitanten om zicht te $\rightarrow 4$ krijgen op persoonlijke levensloop en arbeidsverleden

$\begin{array}{ll}5 & 5 \\ 6 \leftarrow \text { voeren van een rechtzaak voor de } \rightarrow & 6 \\ & \text { Hoge Raad }\end{array}$

12d Moet in de opleiding meer of minder 1 veel meer aandacht aandacht besteed worden aan het 2 meer aandacht ontwikkelen van mondelinge presentatie- 3 niet meer en niet minder vaardigheden?

4 minder aandacht

5 veel minder aandacht

13. Het uitleggen van informatie aan anderen: Het vermogen om uit te leggen wat de informatie betekent en hoe deze gebruikt moet worden

13a Hoe belangrijk is het uitleggen van informatie 1 niet belangrijk

voor het adequaat uitoefenen van uw 2 enigszins belangrijk functie?

3 belangrijk

4 heel belangrijk

5 extreem belangrijk 
$13 b$

Welk niveau van uitleggen van informatie is nodig om uw huidige functie goed uit te oefenen?

$13 c$

Hoe schat $u$ uw eigen niveau van uitleggen van informatie in?
Dublin lists 1 and 2: huidige functie

1

$2 \leftarrow$ uitleggen aan een patiënt wat de $\rightarrow$

eigen niveau betekenis is van de gemeten bloeddruk

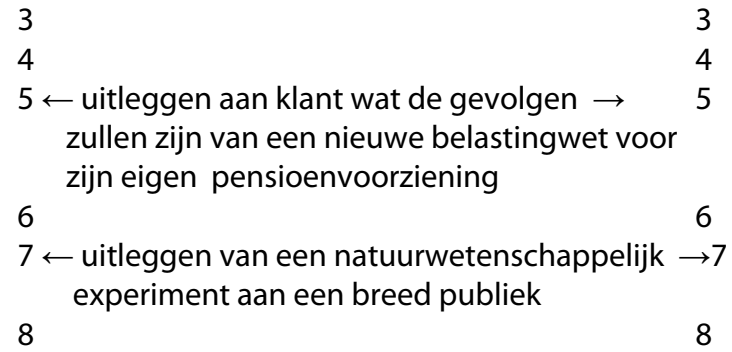

\section{Dublin list 3:}

huidige functie

1 matig

2

3

4

5

6

7

8 uitmuntend

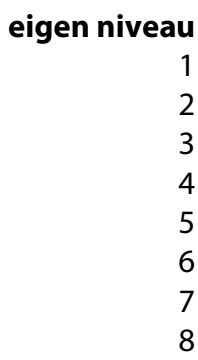

$\begin{array}{lr}\begin{array}{l}\text { Dublin list 4: } \\ \text { huidige functie }\end{array} & \text { eigen niveau } \\ 1 & 1 \\ 2 \leftarrow \text { uitleggen van een bloeddrukmeting } \rightarrow & 2 \\ 3 & 3 \\ 4 \leftarrow \text { uitleggen van buitenlandse } \rightarrow & 4 \\ & \text { belastingwetgeving aan Nederlandse exporteur } \\ 5 & 5 \\ 6 & \text { uitleggen van een complex } \rightarrow\end{array}$

13d Moet in de opleiding meer of minder 1 veel meer aandacht aandacht besteed worden aan het 2 meer aandacht ontwikkelen van het vermogen om informatie 3 niet meer en niet minder goed uit te leggen?

4 minder aandacht

5 veel minder aandacht 
Omschrijving Dublin descriptor 'Leervaardigheden'

\begin{tabular}{|l|l|}
\hline $\begin{array}{l}\text { Kwalificaties } \\
\text { MBO }\end{array}$ & $\begin{array}{l}\text { Bezit de leervaardigheden die noodzakelijk zijn voor een vervolgstudie waarbij een } \\
\text { beperkte mate van autonomie vereist is. }\end{array}$ \\
\hline $\begin{array}{l}\text { Kwalificaties } \\
\text { Bachelors }\end{array}$ & $\begin{array}{l}\text { Bezit de leervaardigheden die noodzakelijk zijn om een vervolgstudie die een hoog niveau } \\
\text { van autonomie veronderstelt aan te gaan. }\end{array}$ \\
\hline $\begin{array}{l}\text { Kwalificaties } \\
\text { Masters }\end{array}$ & $\begin{array}{l}\text { Bezit de leervaardigheden die hem of haar in staat stellen een vervolgstudie aan te gaan } \\
\text { met een grotendeels zelfgestuurd of autonoom karakter. }\end{array}$ \\
\hline
\end{tabular}

Het probleem met deze descriptor is dat ze is toegespitst op een eventuele vervolgstudie, terwijl het concept leervaardigheden natuurlijk ook breder toepasbaar is. We hebben daarom hier geprobeerd een algemene formulering te vinden, waarbij het onderscheid vooral ligt in het zelfsturend vermogen.

Operationalisatie Dublin descriptor 'Leervaardigheden'

\section{Leervaardigheden: Het vermogen om nieuwe kennis te verwerven}

14a Hoe belangrijk zijn leervaardigheden voor het 1 niet belangrijk adequaat uitoefenen van uw functie?

2 enigszins belangrijk

3 belangrijk

4 heel belangrijk

5 extreem belangrijk

14b Welk niveau van leervaardigheden is nodig Dublin lists 1, 2 and 4: om uw huidige functie goed uit te oefenen? huidige functie

eigen niveau

14c Hoe schat $u$ uw eigen niveau van $2 \leftarrow$ kennis en vaardigheden verder ontwikkelen $\rightarrow$ leervaardigheden in? waarbij een beperkte mate van autonomie vereist is

$\begin{array}{lrr}3 & & 3 \\ 4 & & 4 \\ 5 & \leftarrow \text { vanuit eigen inzicht kennis en } \rightarrow & 5 \\ & \text { vaardigheden verder ontwikkelen waarbij } & \\ & \text { het leerproces grotendeels zelfgestuurd is } & \\ 6 & & 6 \\ 7 & \text { - hiaten in eigen kennis onderkennen en } \rightarrow & 7 \\ & \text { kennis uit nieuwe vakgebieden eigen maken } & \\ 8 & 8\end{array}$




\section{Dublin list 3:}

$\begin{array}{lr}\text { huidige functie } & \text { eigen niveau } \\ 1 \text { matig } & 1 \\ 2 & 2 \\ 3 & 3 \\ 4 & 4 \\ 5 & 5 \\ 6 & 6 \\ 7 & 7 \\ 8 \text { uitmuntend } & 8 \\ 1 \text { veel meer aandacht } & \\ 2 \text { meer aandacht } & \\ 3 \text { niet meer en niet minder } & \\ 4 \text { minder aandacht } & \\ 5 \text { veel minder aandacht } & \end{array}$

\section{Leesvaardigheden: Begrijpen van geschreven teksten in werkgerelateerde documenten}

15a Hoe belangrijk zijn leesvaardigheden voor het 1 niet belangrijk

adequaat uitoefenen van uw functie? $\quad 2$ enigszins belangrijk

3 belangrijk

4 heel belangrijk

5 extreem belangrijk

15b Welk niveau van leesvaardigheden is nodig Dublin lists 1 and 2: om uw huidige functie goed uit te oefenen? huidige functie

1

$2 \leftarrow$ begrijpen van een handleiding voor een $\rightarrow 2$

15c Hoe schat u uw eigen niveau van leesvaardigheden in?

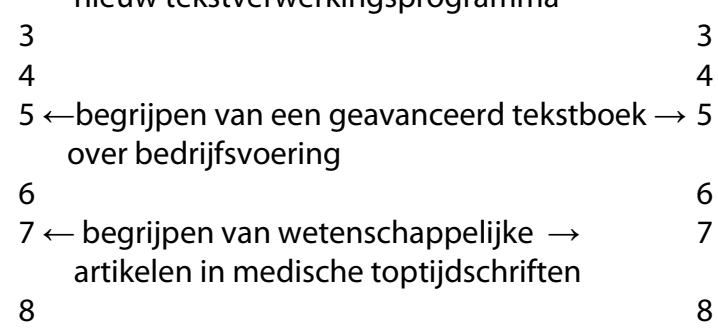

\section{Dublin list 3:}

huidige functie eigen niveau 1 matig

2

3

4

5

6

7

8 uitmuntend 


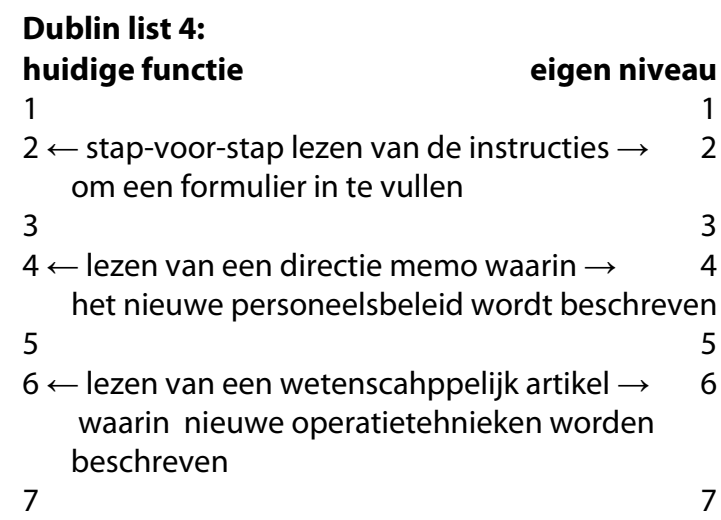

15d Moet in de opleiding meer of minder 1 veel meer aandacht aandacht besteed worden aan het ontwikke- 2 meer aandacht len van leesvaardigheden?

3 niet meer en niet minder

4 minder aandacht

5 veel minder aandacht

\section{Leerstrategieën: Selecteren en gebruiken van training- en instructiemethoden voor nieuwe leersituaties}

16a Hoe belangrijk zijn leerstrategieën voor het 1 niet belangrijk

adequaat uitoefenen van uw functie?

2 enigszins belangrijk

3 belangrijk

4 heel belangrijk

5 extreem belangrijk

16b Welk niveau van leerstrategieën is nodig om uw huidige functie goed uit te oefenen?

Dublin lists 1 and 2: huidige functie

16c Hoe schat u uw eigen niveau van leerstrategieën in? 


$\begin{array}{lr}\text { Dublin list 3: } & \text { eigen niveau } \\ \text { huidige functie } & 1 \\ 1 \text { matig } & 2 \\ 2 & 3 \\ 3 & 4 \\ 4 & 5 \\ 5 & 6 \\ 6 & 7 \\ 7 & 8\end{array}$

\section{Dublin list 4:}

eigen niveau

1

$2 \leftarrow$ een nieuwe werkmethode van een $\rightarrow \quad 2$ collega leren

3

$4 \leftarrow$ ontwikkelen van een nieuwe aanpak om $\rightarrow \quad 4$ trainees te helpen die moeilijkheden hebben 5

$6 \leftarrow$ toepassen van principes uit de $\rightarrow \quad 6$ onderwijspsychologie om nieuwe lesmethoden te ontwikkelen

16d Moet in de opleiding meer of minder 1 veel meer aandacht aandacht besteed worden aan het 2 meer aandacht ontwikkelen van leerstrategieën?

3 niet meer en niet minder

4 minder aandacht

5 veel minder aandacht 


\section{Appendix 2: Original O*NET items}

\section{Originality}

The ability to come up with unusual or clever ideas about a given topic or situation, or to develop creative ways to solve a problem.

A. How important is ORIGINALITY to the performance of your current job?

Not
Important*

* If you marked Not Important, skip LEVEL below and go on to the next activity.

B. What level of ORIGINALITY is needed to perform your current job?

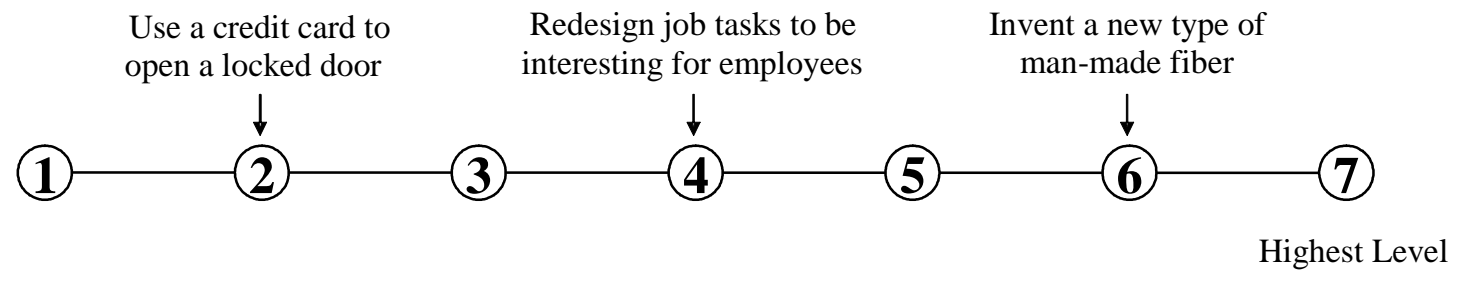




\section{Updating and Using} Relevant Knowledge
Keeping up-to-date technically and applying new knowledge to your job.

A. How important is UPDATING AND USING RELEVANT KNOWLEDGE to the performance of your current job?

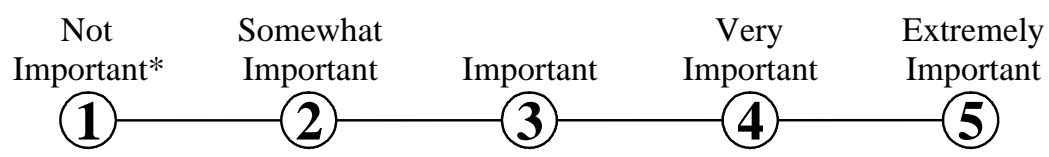

* If you marked Not Important, skip LEVEL below and go on to the next activity.

B. What level of UPDATING AND USING RELEVANT KNOWLEDGE is needed to perform your current job?

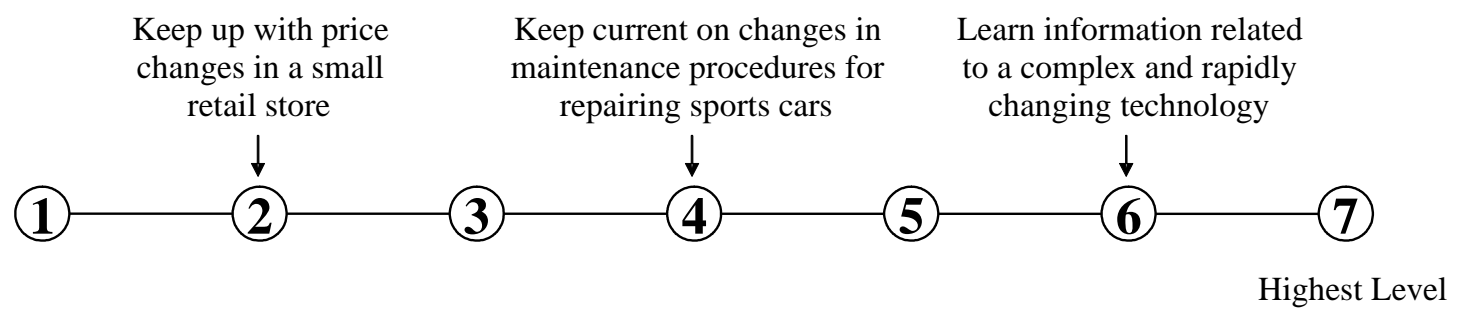




\section{Complex Problem Solving \\ Identifying complex problems and reviewing related information to develop and evaluate options and implement solutions.}

A. How important is COMPLEX PROBLEM SOLVING to the performance of your current job?

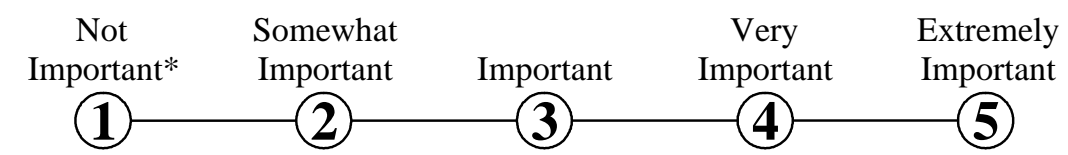

* If you marked Not Important, skip LEVEL below and go on to the next skill.

B. What level of COMPLEX PROBLEM SOLVING is needed to perform your current job?

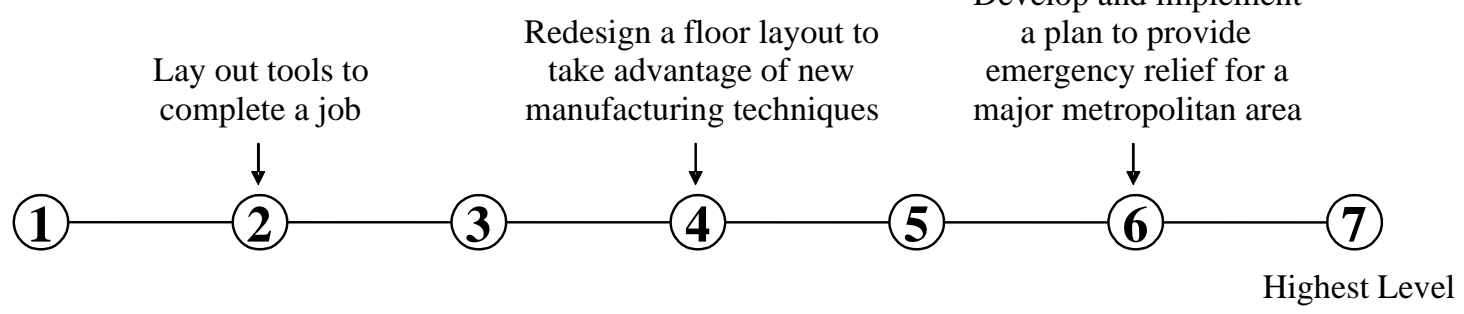

\section{Analyzing Data or Information}

Identifying the underlying principles, reasons, or facts of information by breaking down information or data into separate parts.

A. How important is ANALYZING DATA OR INFORMATION to the performance of your current job?

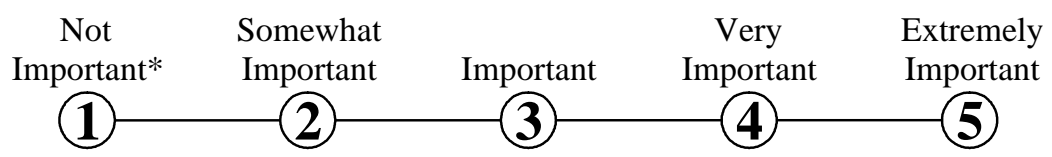

* If you marked Not Important, skip LEVEL below and go on to the next activity. 
B. What level of ANALYZING DATA OR INFORMATION is needed to perform your current job?

Determine the location of a

lost order

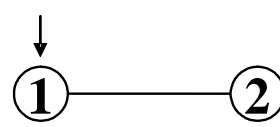

Determine the interest cost to finance

a new building
Analyze the cost of medical care services for all hospitals in the country
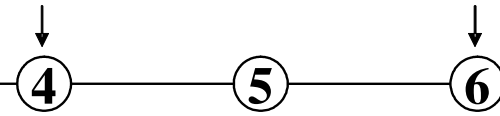

Highest Level

\title{
7. Critical Thinking
}

\begin{abstract}
Using logic and reasoning to identify the strengths and weaknesses of alternative solutions, conclusions, or approaches to problems.
\end{abstract}

A. How important is CRITICAL THINKING to the performance of your current job?

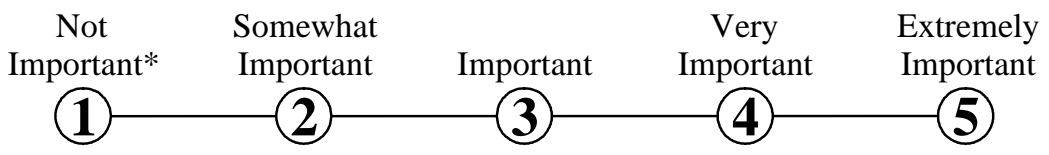

* If you marked Not Important, skip LEVEL below and go on to the next skill.

B. What level of CRITICAL THINKING is needed to perform your current job?

Determine whether a subordinate has a good excuse for being late

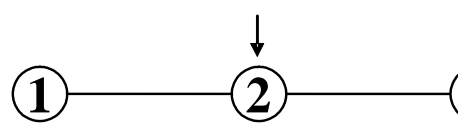

Evaluate customer complaints and determine appropriate responses
Write a legal brief challenging a federal law
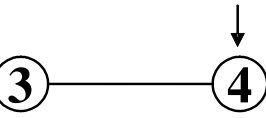

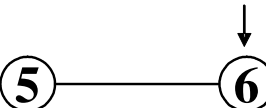

Highest Level

\section{Making Decisions and Solving Problems}

\section{Analyzing information and evaluating} results to choose the best solution and solve problems.

A. How important is MAKING DECISIONS AND SOLVING PROBLEMS to the performance of your current job?

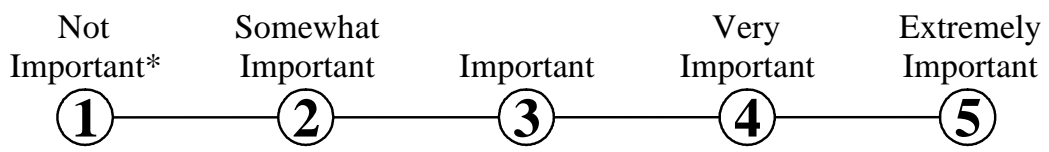

* If you marked Not Important, skip LEVEL below and go on to the next activity. 
B. What level of MAKING DECISIONS AND SOLVING PROBLEMS is needed to perform your current job?

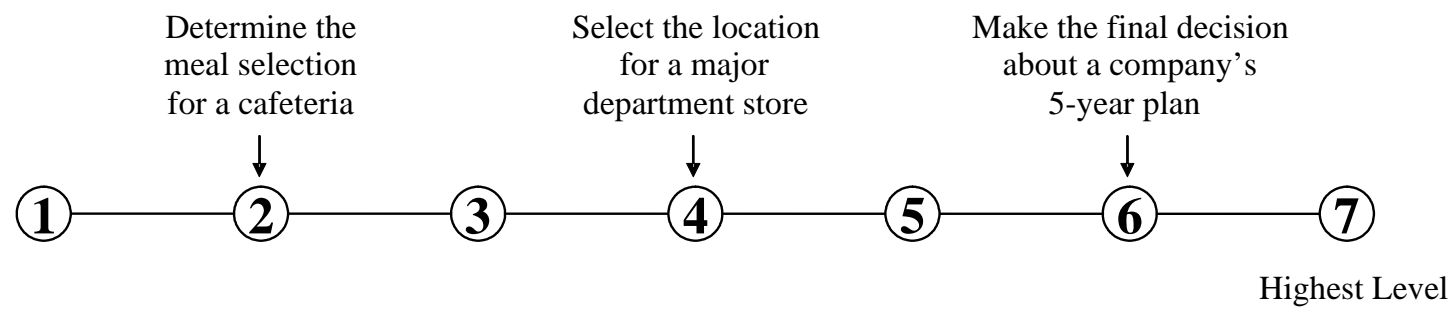

\section{Written Expression}

The ability to communicate information and ideas in writing so others will understand.

A. How important is WRITTEN EXPRESSION to the performance of your current job?

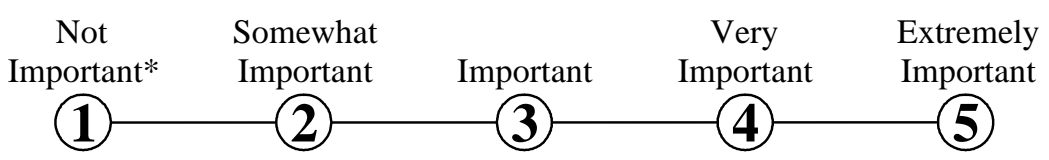

* If you marked Not Important, skip LEVEL below and go on to the next activity.

B. What level of WRITTEN EXPRESSION is needed to perform your current job?

Write a note to remind someone to take food out of the freezer

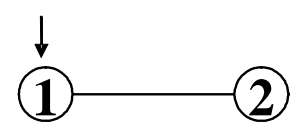

Write a job recommendation for a subordinate
Write an advanced economics texbook

\section{Speaking}

\section{Talking to others to convey information} effectively.

A. How important is SPEAKING to the performance of your current job?

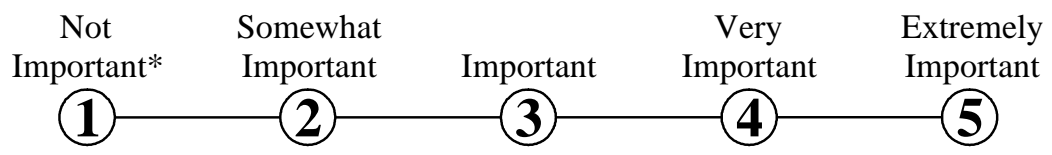

* If you marked Not Important, skip LEVEL below and go on to the next skill. 
B. What level of SPEAKING is needed to perform your current job?

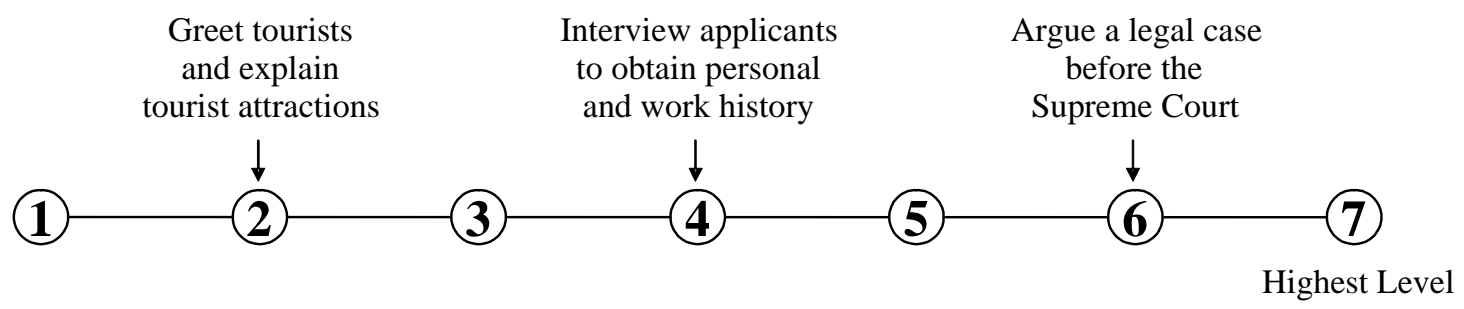

\section{Interpreting the Meaning of Information for Others \\ Translating or explaining what information means and how it can be used.}

A. How important is INTERPRETING THE MEANING OF INFORMATION FOR OTHERS to the performance of your current job?

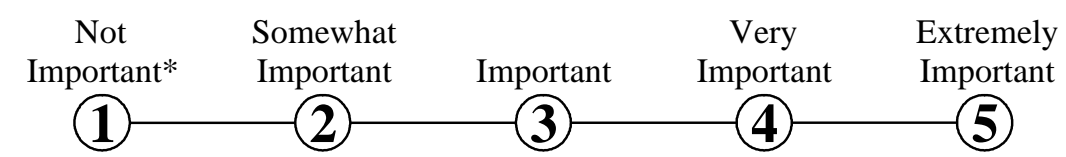

* If you marked Not Important, skip LEVEL below and go on to the next activity.

B. What level of INTERPRETING THE MEANING OF INFORMATION FOR OTHERS is needed to perform your current job?

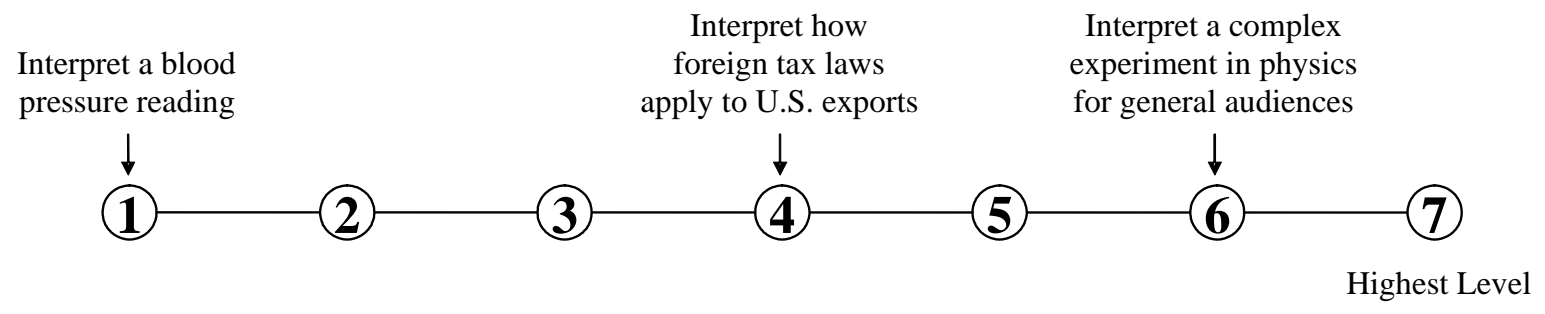




\section{Reading}

Comprehension

A. How important is READING COMPREHENSION to the performance of your current job?

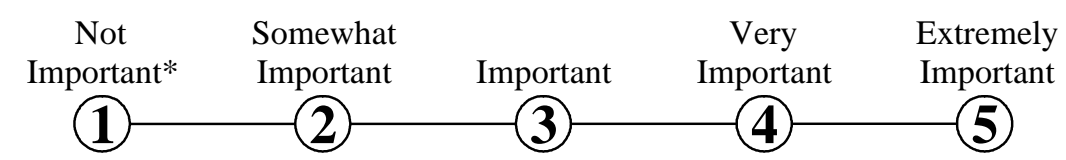

* If you marked Not Important, skip LEVEL below and go on to the next skill.

B. What level of READING COMPREHENSION is needed to perform your current job?
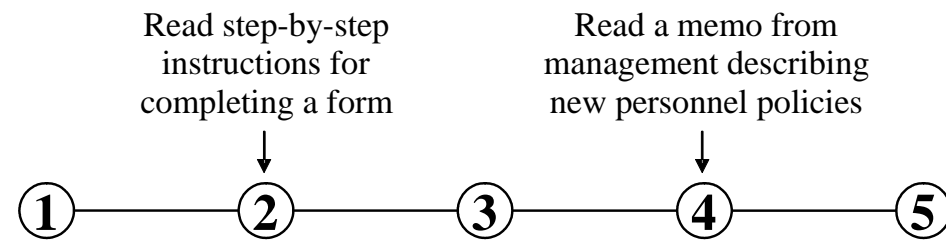

Read a scientific journal article describing surgical procedures

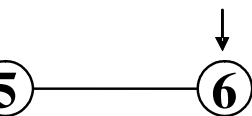

\section{Learning Strategies}

\section{Selecting and using training/instructional methods and procedures appropriate for the situation when learning or teaching new things.}

A. How important are LEARNING STRATEGIES to the performance of your current job?

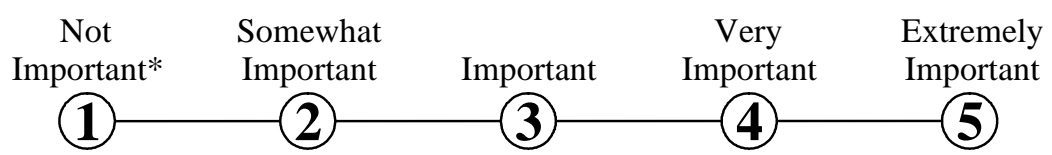

* If you marked Not Important, skip LEVEL below and go on to the next skill. 
B. What level of LEARNING STRATEGIES is needed to perform your current job?

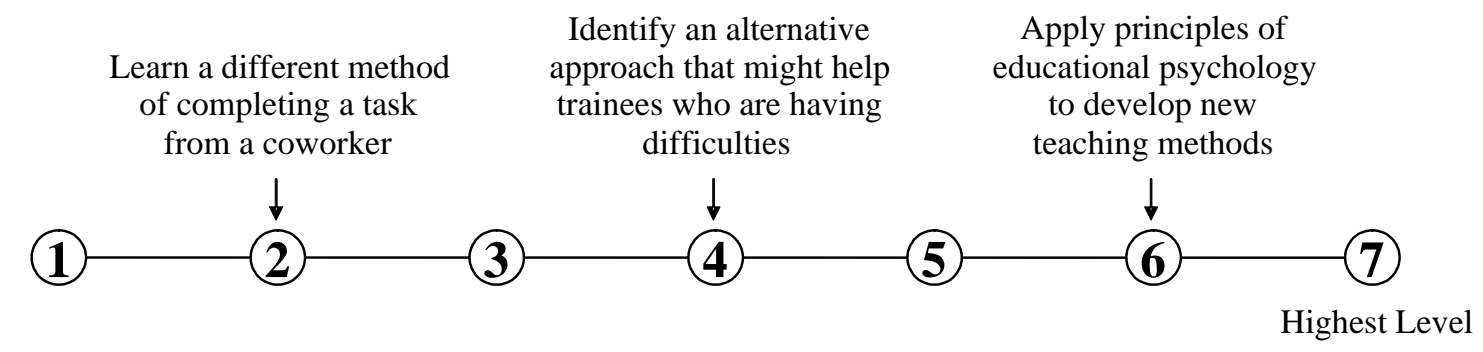

